\title{
The Geographical Composition of National External Balance Sheets: 1980-2005*
}

\author{
Chris Kubelec a and Filipa Sáb

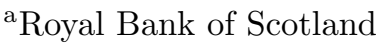 \\ ${ }^{\mathrm{b}}$ Trinity College, University of Cambridge
}

This paper constructs a data set on the stocks of bilateral external assets and liabilities for eighteen countries in the period from 1980 to 2005. It distinguishes between four asset classes: foreign direct investment, portfolio equity, debt, and foreign exchange reserves. Network methods are used to explore the key facts that emerge from the data. We find that there has been a remarkable increase in interconnectivity over the past two decades and that this has been centered around a small number of countries. In a simulation exercise we show that shocks to one of the central countries generate much larger losses to the network than shocks to the periphery.

JEL Code: F3.

\section{Introduction}

Financial globalization was one of the most striking phenomena of the last two decades. But until recently very little was known about the size and composition of countries' external financial assets and liabilities. This gap was partly narrowed by the work of Lane and

* An earlier version of this paper was published as Bank of England Working Paper No. 384 (Copyright (C) 2010 Bank of England). Suggestions from an anonymous referee substantially improved the paper. We wish to thank Philip Lane, Vasileios Madouros, and Peter Sinclair for helpful discussions. We also wish to thank Gian Maria Milesi-Ferretti and Andreas Baumann for help with data. Participants at the Bank of England seminar and at the BIS CGFS workshop on the use of BIS international financial statistics provided useful comments. Amy Varty and Richard Edghill provided excellent research assistance. The data set constructed in this paper is available at www.econ.cam.ac.uk/teach/filipasa/publications.htm. Corresponding author (Sá) address: Trinity College, Trinity Street, CB2 1TQ, Cambridge, UK. Tel.: +44 1223337731. E-mail: fgs22@cam.ac.uk. 
Milesi-Ferretti (2001, 2007), which provides estimates of the total external financial assets and liabilities of 145 countries from 1970 to 2007. These data cover different asset classes - foreign direct investment (FDI), portfolio equity, debt, financial derivatives, and foreign exchange reserves - and show that there has been a marked increase in the ratio of foreign assets and liabilities to GDP, particularly since the mid-1990s. This increase has been especially pronounced among industrial countries, where financial integration has exceeded trade integration. However, very little is known about the geographical composition of external assets and liabilities.

The key contribution of this paper is to go beyond total external assets and liabilities by constructing a data set of stocks of bilateral assets and liabilities. Our study is pioneer in providing a comprehensive picture of bilateral external assets and liabilities across countries. Existing data sets suffer from several gaps along both a cross-sectional and time-series dimension. This paper fills these gaps and constructs a complete data set of bilateral external positions for a group of eighteen countries, covering the period from 1980 to 2005.

Another contribution of our study is to provide a global perspective across asset classes. Existing studies on bilateral financial flows and stocks focus on a single asset class. This paper looks at four different asset classes: FDI, portfolio equity, debt, and foreign exchange reserves. For FDI, equity, and debt we collect data from a variety of sources and fill gaps using gravity models, which are the workhorse models for trade in goods. They explain trade flows between countries $i$ and $j$ by their sizes (GDP) and a variety of variables capturing the geographical and historical proximity between the two countries (distance, common language, common border, colonial links, etc.). These models have more recently been applied to bilateral financial stocks and flows. For reserves we adopt a different procedure and start by constructing the currency composition, which is then translated into the geographical composition.

Martin and Rey (2004) develop a theoretical framework that delivers an equilibrium relation between bilateral asset flows, the size of the home and host countries, and transportation and information costs. Their model provides a theoretical foundation for gravity models applied to trade in assets. Okawa and van Wincoop (2010) add information asymmetries to a static portfolio choice model. Similarly 
to Martin and Rey, their model delivers an equation where bilateral asset holdings are driven by the size of the source and host countries and the information asymmetry between them. Because the information asymmetry cannot be directly observed, it is captured empirically by variables such as the distance between the two countries, whether they share a common border or a common language, etc.

Empirically these models have been applied to different asset classes. Stein and Daude (2007) focus on the determinants of FDI stocks in OECD countries in the late 1990s and find that differences in time zones have a negative and significant effect on the location of FDI. Portes and Rey (2005) use a gravity model to explain bilateral cross-border equity flows between fourteen economies in the period from 1989 to 1996. They find that the model performs at least as well as when applied to trade in goods and there is a significant and negative effect of distance on equity transactions. Lane and MilesiFerretti (2008) use a gravity model to explain stocks of bilateral portfolio equity in 2001 . They find that bilateral equity holdings are strongly correlated with bilateral trade in goods and services and are also positively associated with measures of proximity. Rose and Spiegel (2004) use a gravity equation to explain bilateral debt flows and also find that bilateral trade appears to have a positive and significant effect on bilateral lending.

Consistent with previous studies, we find gravity models to have very good explanatory power when applied to bilateral financial stocks. Standard gravity variables have a significant effect on financial stocks: countries that are less distant or share a common border or a common language have stronger financial linkages across all three asset classes. We also confirm the findings in Stein and Daude (2007) on the negative effect of time difference on FDI stocks and find that this is true for equity and debt holdings as well.

The idea that variables such as distance and cultural affinities may explain a large proportion of cross-border asset flows and stocks is perhaps surprising. Unlike goods, financial assets are not subject to transportation costs. Also, if investors wish to diversify their portfolios, they may choose to invest in more distant countries, where the business cycle has a low or negative correlation with their own country's business cycle. The fact that gravity variables perform at least 
as well in explaining financial positions as they do in explaining trade suggests that financial markets are not frictionless but are segmented by information asymmetries and familiarity effects.

After describing the data construction in detail, we apply a number of tools from network analysis to examine the key stylized facts that emerge from the data. The international financial system can be seen as a network, where nodes represent countries and links represent bilateral financial assets. We observe that there has been a remarkable increase in interconnectivity over the past two decades: financial links have become larger and countries have become more open. We also find that the global financial network is centered around a small number of nodes, which have many and large links.

The global trade network also shows an increase in interconnectivity over time. However, while the financial network is centered around the United States and the United Kingdom, the trade network shows strong intracontinental links and is arranged in three clusters: a European cluster (centered on Germany), an Asian cluster (centered on China), and an American cluster (centered on the United States).

The configuration of the international financial network has important implications for the stability of the international financial system. We discuss how the combination of high interconnectivity and a small number of hubs makes for a "robust yet fragile" system, where a disturbance to one of the central countries would be transmitted rapidly and widely. To illustrate how shocks propagate through the network, we perform a simulation exercise where asset values in the shock country drop by 10 percent. This exercise shows that the largest losses to the network occur after a shock to the United States: the value of all other countries' assets as a percentage of their GDP falls by 7 percent. The countries that suffer the largest losses following a shock to the United States are the other "hubs" in the network: Hong Kong, Singapore, and the United Kingdom. By contrast, shocks to peripheral countries have a much smaller effect: shocks to Argentina, India, Portugal, Mexico, and Brazil all generate losses of less than 0.4 percent of the combined GDP of all countries except the shock country.

The rest of the paper is organized as follows. Section 2 describes data sources on bilateral financial assets and liabilities and the 


\section{Table 1. Country Coverage}

\begin{tabular}{|l|l|}
\hline Developed Countries & Emerging Markets \\
\hline Australia & Argentina \\
Canada & Brazil \\
France & Mexico \\
Germany & China \\
Italy & Hong Kong \\
Japan & India \\
Portugal & Korea \\
Spain & Singapore \\
United Kingdom & \\
United States & \\
\hline
\end{tabular}

techniques used to fill in gaps in those sources. Section 3 uses network methods to show the key stylized facts that emerge from the data and compares the international financial and trade networks. Section 4 discusses the implications of the configuration of the international financial network for the stability of the international financial system. Section 5 concludes.

\section{Data Construction}

\subsection{Country Selection and Treatment of Financial Centers}

The data are constructed at annual frequency and include eighteen countries, listed in table 1 . The sample was selected to include both emerging and developed economies located in different continents. To measure the proportion of total external assets that is accounted for by our sample, we use the data compiled by Lane and MilesiFerretti and compute the share of total external assets in their sample of 145 countries that is accounted for by the 18 countries in our sample.

Figure 1 shows how this share has changed over time for different asset classes. Until the late 1990s, the share of the world's total external assets excluding reserves accounted for by our sample was between 70 percent and 90 percent. This fraction dropped to around 60 percent in the 2000s. The five countries outside our sample whose 


\section{Figure 1. Percentage of World's Total Assets Accounted for by the Eighteen Countries in Our Sample}

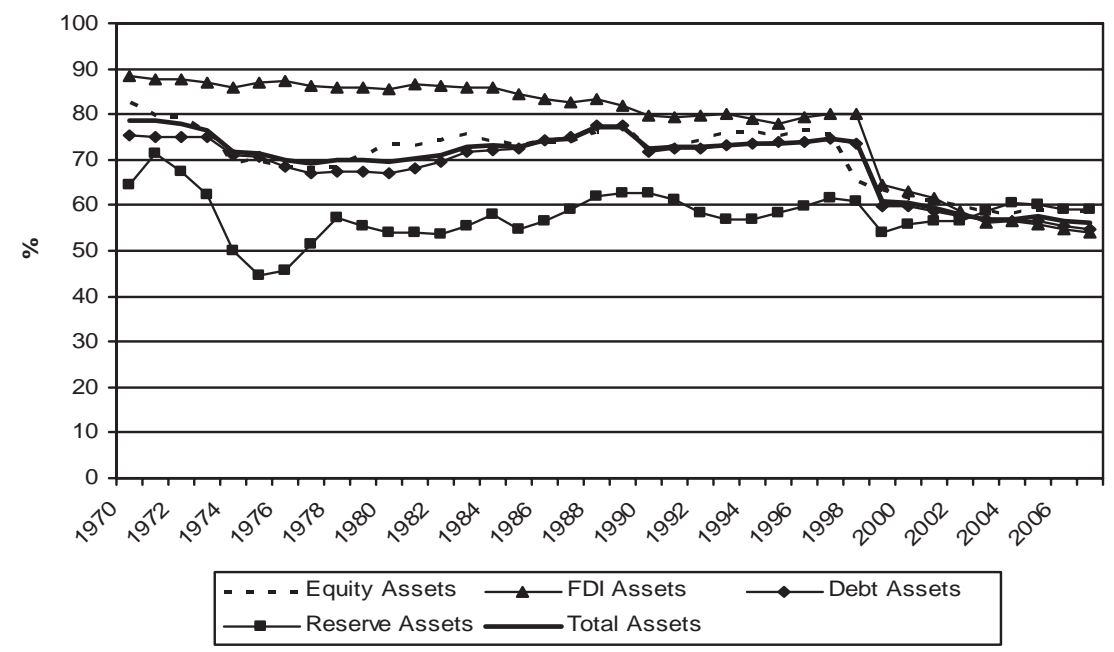

Source: Lane and Milesi-Ferretti (2001, 2007) data set.

shares of the world's total external assets excluding reserves most increased from 1997 to 2007 were Ireland and Luxembourg (which are financial centers), Norway, the Netherlands, and Austria. These five countries accounted for about 9 percent of the world's total external assets excluding reserves in 1997 and 14 percent in 2007. Given that the share accounted for by the eighteen countries in our sample dropped by about 20 percentage points in this period, this implies that the gains in share were distributed over a large number of countries. Our sample captures between 50 percent and 60 percent of the world's total reserves.

Some of the countries in the sample - the United Kingdom, the United States, Singapore, and Hong Kong - are important financial centers and are both final destinations and intermediaries of foreign investment. Balance-of-payments statistics are constructed on the basis of the residence principle. For example, if a German resident invests in a Chinese company and directs the investment via a financial institution located in the United Kingdom, balance-of-payments data would register the transaction as an asset of Germany in the 
United Kingdom and an asset of the United Kingdom in China, even though the United Kingdom has only acted as an intermediary. ${ }^{1}$

Most available data sets on bilateral financial links follow the residence principle. A notable exception is the Bank for International Settlements (BIS) consolidated banking statistics, which contain information on cross-border assets held by banks and are based on the nationality of the reporting bank, netting out intragroup positions. The BIS also collects data based on residence (locational banking statistics). ${ }^{2}$ Which data are preferable depends on the question being addressed. Data based on residence are useful to detect broad trends in cross-border links from a geographical perspective, while data based on nationality may be preferable for analyzing the international transmission of shocks through the banking system. However, this depends on whether foreign subsidiaries and branches fund themselves locally or in their country of nationality. For example, suppose that Santander in the United Kingdom (part of a Spanish group) borrows from households in the United Kingdom to lend to China. Consolidated data would treat this as an investment of Spain in China. This may be appropriate to study the effect of a shock in China on Santander as a group. However, it would not be appropriate to study the implications of a shock in the United Kingdom for cross-border capital flows. For this question locational data would be preferable. Since no type of data is clearly preferable in all circumstances and residence-based data are more widely available, we follow the balance-of-payments methodology and construct the data set based on the residence principle.

\subsection{General Approach for FDI, Equity, and Debt}

The construction of data for FDI, equity, and debt follows a six-step procedure:

- Step 1. Collect data on bilateral assets from a variety of sources.

\footnotetext{
${ }^{1}$ Felettigh and Monti (2008) show that there can be significant differences between bilateral links based on the residence principle and ultimate exposures.

${ }^{2}$ The BIS consolidated banking statistics are described in detail in McGuire and Wooldridge (2005). For a useful discussion of the differences between consolidated and locational baking statistics, see McGuire and Tarashev (2008).
} 
- Step 2. Compute geographical weights.

By dividing assets of country $i$ in country $j\left(A_{i j t}\right)$ by total external assets of country $i\left(A_{i t}\right)$, obtain the percentage of assets of country $i$ which are held in country $j\left(w_{i j t}\right)$ :

$$
w_{i j t}=\frac{A_{i j t}}{A_{i t}} .
$$

Weights do not necessarily add up to 1 , since the eighteen countries in the sample do not account for a country's total external assets.

- Step 3. Estimate gravity models for geographical weights.

Missing data are estimated separately for each asset class using the following gravity model:

$$
\log \left(\frac{w_{i j t}}{1-w_{i j t}}\right)=\phi_{i}+\phi_{j}+\phi_{t}+\alpha X_{i j}+\beta Z_{i j t}+\varepsilon_{i j t} .
$$

$w_{i j t}$ is the proportion of assets of country $i$ held in country $j$ in year $t$. We estimate the model on weights rather than stocks of foreign assets because stocks would be non-stationary, implying that the usual distributions for OLS estimates would be invalid. The dependent variable is the logit of weights. This is a standard transformation to deal with proportions data, transforming (1) into a linear model which can be estimated by OLS. ${ }^{3}$

$\phi_{i}$ and $\phi_{j}$ are dummy variables for each source and host country and $\phi_{t}$ are time dummies. Host-country fixed effects control for characteristics that make countries attractive to foreign investment. Source-country fixed effects control for characteristics that make countries more diversified, investing a smaller share in a larger number of countries. $X_{i j}$ is a set of bilateral variables which are standard in trade gravity

\footnotetext{
${ }^{3}$ Taking logs eliminates observations for which weights are zero. Given the small proportion of zeros in the data (less than 10 percent), eliminating them should not have much influence on the results. Also, eliminating zeros may be less problematic than estimating a model that fits over both zero and non-zero observations. This is because the determinants of whether a country has any financial linkages with another country may be different from the determinants of the size of the exposures, given that countries are linked.
} 
models and measure the geographical and historical proximity between economies: common border, common language, colonial links, distance, and time difference. The colony dummy is asymmetric and is equal to 1 if country $i$ is a former colonizer of country $j$. This variable is asymmetric to reflect the fact that while former colonizers may have preferential status when they invest in former colonies, former colonies may not have preferential status when investing in former colonizers. $Z_{i j t}$ is a set of time-varying regressors.

- Step 4. Combine actual with estimated weights.

After estimating gravity models for geographical weights, we use the estimated coefficients to obtain out-of-sample predictions of weights for those years and country pairs for which data are missing. We then combine actual weights with those predicted values to obtain a data set on asset weights with no missing observations $\left(\tilde{w}_{i j t}\right)$.

- Step 5. Transform geographical weights into stocks of foreign assets.

To transform geographical weights into stocks of foreign assets, we multiply the weights obtained in step 4 by total external assets of country $i$ reported in the Lane and MilesiFerretti (2007) data set:

$$
\widetilde{A}_{i j t}=\tilde{w}_{i j t} \times A_{i t, L M F} .
$$

This step ensures that bilateral stocks of foreign assets incorporate some adjustment for valuation effects arising from exchange rate movements and changes in asset prices. Lane and Milesi-Ferretti introduce this adjustment in their data; therefore it will also be incorporated into our estimates of bilateral stocks. This is potentially important, since valuation effects have been shown to be sizable (see Gourinchas and Rey 2007b). ${ }^{4}$

\footnotetext{
${ }^{4} \mathrm{~A}$ more accurate method to adjust for valuation effects would be to do it directly on bilateral stocks, taking into account changes in bilateral exchange rates and in stock market valuations in the host country. By taking the adjustment from Lane and Milesi-Ferretti, we are applying the adjustment on total external assets to bilateral assets, rather than making it specific to each country pair.
} 
- Step 6. Construct liabilities from assets.

The data set is constructed taking the assets perspective. This last step uses the fact that assets and liabilities should be symmetric and constructs liabilities from assets:

$$
\text { Liabilities }_{i j t}=\text { Assets }_{j i t} .
$$

Liabilities of country $i$ with country $j$ at year $t$ equal assets of country $j$ in country $i$ at year $t$.

\section{$2.3 \quad F D I$}

\subsubsection{Data}

The main source of data on FDI assets is the OECD International Direct Investment by Country data set, which contains FDI data at book value reported by OECD members starting in 1981. There are many missing values in the data. To the extent possible, missing observations are filled with data from the United Nations Conference on Trade and Development (UNCTAD). But even after combining the data sets, there are significant gaps in the data. Table 2 lists the percentage of missing data for each source country. Coverage is better for developed economies, but there is a large fraction of missing data for Mexico, Argentina, and India. Overall, approximately 44 percent of the data on bilateral FDI are missing and need to be estimated.

Because the OECD and UNCTAD report data on both assets and liabilities, it would in principle be possible to combine the two and reduce the extent to which bilateral positions need to be estimated. We do not follow this approach because different methods are used to report FDI assets and liabilities. Liabilities are reported following the ultimate beneficial owner (UBO) principle, according to which the source of inward FDI is allocated to the country of ultimate ownership. The equivalent principle on the assets side would be the country of ultimate destination (CUD) principle, according to which outward FDI would be allocated to the country of final destination. However, while the UBO principle is widely adopted in the production of FDI statistics, the CUD principle is not the norm; i.e., liabilities are reported following the ultimate ownership principle and assets are reported following the residence principle adopted 
Table 2. Proportion of Missing Data

\begin{tabular}{|l|c|c|c|}
\hline Source Country & FDI & Equity & Debt \\
\hline Argentina & $84 \%$ & $63 \%$ & $76 \%$ \\
Australia & $40 \%$ & $68 \%$ & $62 \%$ \\
Brazil & $67 \%$ & $68 \%$ & $78 \%$ \\
Canada & $3 \%$ & $63 \%$ & $0 \%$ \\
China & $76 \%$ & $89 \%$ & $94 \%$ \\
France & $19 \%$ & $63 \%$ & $0 \%$ \\
Germany & $0 \%$ & $67 \%$ & $0 \%$ \\
Hong Kong & $77 \%$ & $72 \%$ & $79 \%$ \\
India & $84 \%$ & $84 \%$ & $76 \%$ \\
Italy & $26 \%$ & $63 \%$ & $0 \%$ \\
Japan & $15 \%$ & $63 \%$ & $78 \%$ \\
Korea & $15 \%$ & $68 \%$ & $86 \%$ \\
Mexico & $86 \%$ & $85 \%$ & $62 \%$ \\
Portugal & $52 \%$ & $65 \%$ & $77 \%$ \\
Singapore & $54 \%$ & $64 \%$ & $11 \%$ \\
Spain & $76 \%$ & $64 \%$ & $0 \%$ \\
United Kingdom & $16 \%$ & $64 \%$ & $0 \%$ \\
United States & $6 \%$ & $63 \%$ & $\mathbf{4 3 \%}$ \\
\hline Full Sample & $\mathbf{4 4 \%}$ & $\mathbf{6 9 \%}$ & \\
\hline Notes: Proportions are computed after filling in missing values using the index of \\
stock market liberalization. For equity, the CPIS only reports data for 1997 and the \\
period from 2001 to 2005. Data for all other years are missing. For debt, data for \\
Argentina, China, Hong Kong, Korea, and Singapore are from the IMF CPIS only. \\
Therefore, data are missing for all years except 1997 and 2001 to 2005. \\
\hline
\end{tabular}

in the balance-of-payments statistics. Since we choose to follow the balance-of-payments methodology, we focus only on assets and make no use of data on liabilities.

\subsubsection{Estimation}

FDI asset weights are estimated using model (1). The gravity variables are obtained from the Distances Database compiled by the Centre d'Etudes Prospectives et d'Informations Internationales (CEPII). The set of time-varying regressors includes GDP per capita in countries $i$ and $j$ and the degree of openness of country $j$ to inward 
FDI. GDP per capita captures the degree of development and is obtained from the World Bank's World Development Indicators. It is measured at constant prices and is PPP adjusted. The degree of openness of country $j$ to inward FDI is a time-varying index constructed from the tables in Kaminsky and Schmukler (2003), which report the chronology of stock market liberalization and classify countries into three degrees of liberalization over time:

(i) No liberalization: Foreign investors are not allowed to hold domestic equity and cannot repatriate capital, dividends, and interest until five years after the initial investment.

(ii) Partial liberalization: The country is open to foreign investment, but with some restrictions.

(iii) Full liberalization: Foreign investors are allowed to hold domestic equity and to repatriate capital, dividends, and interest without restrictions.

We transform this classification into a numerical variable which takes the value 0 if country $j$ is not liberalized in year $t, 1$ if it is partially liberalized, and 2 if it is fully liberalized. ${ }^{5}$ As well as being used as a control in regression (1), this index is used to fill in some of the missing data prior to estimation. Table 3 illustrates how this is done, using as an example FDI assets of the United Kingdom in China. We know the stock of assets of the United Kingdom in China in 1991, while China was still closed to FDI. Because there would have been no inward flows to China from 1980 to 1990, the stock of assets in that period should equal the stock in 1991, adjusted for valuation effects due to changes in exchange rates and asset prices. To adjust for valuation effects, we assume that FDI assets of the United Kingdom in China in that period grow at the same rate as

\footnotetext{
${ }^{5}$ Some countries in our sample are not studied by Kaminsky and Schmukler (2003). For those countries, we use information on the timing of stock market liberalization from other studies and code it according to the criteria used by Kaminsky and Schmukler. For China we use information in OECD (2000), Prasad and Wei (2005), and Bekaert, Harvey, and Lundblad (2007). For India we use Ahluwalia (2002) and Reserve Bank of India (2006).
} 
Table 3. Using the Liberalization Index on Inward FDI to Fill in Missing Data

\begin{tabular}{|c|c|c|}
\hline Year & $\begin{array}{c}\text { FDI Assets of } \\
\text { United Kingdom } \\
\text { in China }\end{array}$ & $\begin{array}{c}\text { Liberalization Index } \\
\text { on Inward FDI } \\
\text { FDI in China }\end{array}$ \\
\hline 1980 & 8 & 0 \\
\hline 1981 & 8 & 0 \\
\hline 1982 & 10 & 0 \\
\hline 1983 & 13 & 0 \\
\hline 1984 & 19 & 0 \\
\hline 1985 & 30 & 0 \\
\hline 1986 & 44 & 0 \\
\hline 1987 & 60 & 0 \\
\hline 1988 & 77 & 0 \\
\hline 1989 & 100 & 0 \\
\hline 1990 & 124 & 0 \\
\hline 1991 & 150 & 0 \\
\hline 1992 & 157 & 1 \\
\hline 1993 & 271 & 1 \\
\hline 1994 & 184 & 1 \\
\hline 1995 & 270 & 1 \\
\hline 1996 & 778 & 1 \\
\hline 1997 & 776 & 1 \\
\hline 1998 & 566 & 1 \\
\hline 1999 & 2027 & 1 \\
\hline 2000 & 2246 & 1 \\
\hline 2001 & 3055 & 1 \\
\hline 2002 & 5177 & 1 \\
\hline 2003 & 3229 & 1 \\
\hline 2004 & 3645 & 1 \\
\hline 2005 & 5364 & 1 \\
\hline
\end{tabular}

total Chinese FDI liabilities. We take the value in 1991 as the starting point and build stocks backwards using the growth rate of total Chinese liabilities.

Turning to the estimation results, column 1 of table 4 reports results of a model where FDI asset weights are only explained by 
Table 4. Estimation Results for FDI Weights

\begin{tabular}{|c|c|c|c|c|}
\hline & (1) & (2) & (3) & (4) \\
\hline & $\begin{array}{l}\text { Host- } \\
\text { Country } \\
\text { FE }\end{array}$ & $\begin{array}{c}\text { Host- and } \\
\text { Source- } \\
\text { Country FE }\end{array}$ & $\begin{array}{c}\text { Gravity } \\
\text { Variables }\end{array}$ & $\begin{array}{c}\text { Model } \\
\text { for } \\
\text { Prediction }\end{array}$ \\
\hline $\begin{array}{l}\text { Border } \\
\text { Language } \\
\text { Colony } \\
\text { Log(Distance) } \\
\text { Time Difference } \\
\text { Log }\left(G D P p c_{i t}\right) \\
\text { Log }\left(G D P p c_{j t}\right) \\
\text { Index Liberalization } \\
\quad \mathrm{FDI}_{j t}\end{array}$ & & & $\begin{array}{c}0.394^{* * *} \\
(0.119) \\
1.585^{* * *} \\
(0.095) \\
0.507^{* * *} \\
(0.092) \\
-0.681^{* * *} \\
(0.043) \\
-0.054^{* * *} \\
(0.010)\end{array}$ & $\begin{array}{c}0.340^{* * *} \\
(0.113) \\
1.598^{* * *} \\
(0.094) \\
0.481^{* * *} \\
(0.096) \\
-0.681^{* * *} \\
(0.040) \\
-0.054^{* * *} \\
(0.009) \\
0.750^{* * *} \\
(0.295) \\
1.817^{* * *} \\
(0.137) \\
0.379^{* * *} \\
(0.054)\end{array}$ \\
\hline $\begin{array}{l}N \\
R^{2} \\
\text { Marginal } R^{2} \text { of } \\
\quad \text { Gravity Variables } \\
\text { Marginal } R^{2} \text { of } \\
\text { Time-Varying } \\
\text { Variables }\end{array}$ & $\begin{array}{l}3810 \\
0.41\end{array}$ & $\begin{array}{l}3810 \\
0.50\end{array}$ & $\begin{array}{l}3810 \\
0.68 \\
0.36\end{array}$ & $\begin{array}{l}3810 \\
0.71\end{array}$ \\
\hline $\begin{array}{l}\text { Notes: Robust standa } \\
\text { percent level, }{ }^{* *} \text { at the } \\
\text { (4) includes time dumr } \\
\text { percentage improvemer } \\
\text { the model with only ho } \\
\text { varying variables indic } \\
\text { varying variables (incl } \\
\text { effects and the gravity }\end{array}$ & $\begin{array}{l}\text { rors are i } \\
\text { percent le } \\
\text { The mar } \\
\text { the } R^{2} \mathrm{f} \\
\text { nd source- } \\
\text { the perce } \\
\mathrm{g} \text { time du } \\
\text { ables. }\end{array}$ & $\begin{array}{l}\text { parentheses. }{ }^{*} \\
\text { el, and }{ }^{* * *} \text { at th } \\
\text { inal } R^{2} \text { of the } \\
\text { om including th } \\
\text { country fixed effe } \\
\text { tage improveme } \\
\text { nmies) over and }\end{array}$ & $\begin{array}{l}\text { otes signific } \\
\text { percent le } \\
\text { ity variable } \\
\text { variables, o } \\
\text { The margil } \\
\text { in the } R^{2} \mathrm{f} \\
\text { ove the mo }\end{array}$ & $\begin{array}{l}\text { lce at the } 10 \\
\text { l. Regression } \\
\text { indicates the } \\
\text { r and above } \\
l R^{2} \text { of time- } \\
\text { m the time- } \\
\text { l with fixed }\end{array}$ \\
\hline
\end{tabular}

host-country fixed effects. The predictive power is relatively good, with an $R^{2}$ of 41 percent. Column 2 adds source-country fixed effects, with an improvement in the $R^{2}$ to 50 percent. Including the standard gravity variables further increases the $R^{2}$ to 68 percent, which is 
high and consistent with the results in other empirical studies. The standard gravity variables are significant and have the expected signs: FDI weights are larger for countries that share a common border or a common language and have colonial links. Distance and time difference have a significant negative effect on FDI weights.

Time-varying controls are included in column 4. Countries with larger GDP per capita receive larger shares of FDI investment. This illustrates the paradox discussed in Lucas (1990) — that capital tends to flow to rich countries even though the marginal product of capital is larger in poor countries - and is consistent with the findings in Papaioannou (2009). Countries whose markets are more liberalized to FDI also receive larger investment shares. However, the improvement in the $R^{2}$ from including these time-varying controls is marginal.

We also experimented with additional controls. Previous studies have found a significant effect of bilateral trade on bilateral asset holdings. There are at least two reasons why this may be the case. First, bilateral trade may capture an additional familiarity effect, over and above the gravity variables. Second, countries may use financial investment to hedge against shocks in countries with which they trade. We extended the model to include trade weights, measured as the ratio of trade (exports plus imports) between countries $i$ and $j$ over total trade of country $i$, using data from the International Monetary Fund (IMF) Direction of Trade Statistics (DOTS). Trade weights were found to have a positive but insignificant effect in explaining FDI weights and were not included in the model used for prediction. ${ }^{6}$

Another variable we experimented with was the volatility in bilateral exchange rates measured as the standard deviation in the rate of change of monthly bilateral exchange rates on a three-year rolling window. Exchange rates were obtained from the IMF International Financial Statistics (IFS). Bilateral financial positions may be smaller when the bilateral exchange rate is more volatile because there is more uncertainty about the returns. This variable turned out to have an insignificant effect on FDI asset weights and was

\footnotetext{
${ }^{6}$ Only variables with a p-value lower than 0.25 were kept in the model used for prediction.
} 
excluded from the model used for prediction. The insignificant effect of bilateral exchange rates is consistent with the findings in Portes and Rey (2005) and Lane and Milesi-Ferretti (2008).

\subsection{Equity}

\subsubsection{Data}

Data on portfolio equity assets are collected from the IMF Coordinated Portfolio Investment Survey (CPIS), which covers all countries in our sample except China. The time coverage, though, is quite limited: a pilot survey was conducted in 1997 and a regular annual survey was introduced in 2001 for an extended group of participating countries. Table 2 lists the proportion of missing data by source country. Given limited time coverage of the CPIS, over 60 percent of data are missing for all countries and need to be estimated. For China this proportion is higher since it does not participate in the CPIS.

As for FDI, we only use data on assets and make no use of data on liabilities. This is because, while countries that participate in the CPIS are required to report assets, liabilities are reported on a voluntary basis. For the few countries in our sample that report liabilities, there is a big discrepancy between liabilities and assets reported by creditors. Because of this discrepancy, we use only reported assets.

\subsubsection{Estimation}

Table 5 shows the results of estimating model (1) on equity weights. Host-country fixed effects explain 46 percent of the variation in equity weights. Introducing source-country fixed effects increases the $R^{2}$ to 55 percent. The coefficients on the gravity variables are significant and have the expected signs except for colonial links, which is negative. This suggests that investors may prefer to invest in countries with a similar degree of development as their home country regardless of historical colonial links. The inclusion of these variables leads to a significant improvement in the $R^{2}$, which rises to 71 percent. 
Table 5. Estimation Results for Equity Weights

\begin{tabular}{|c|c|c|c|c|}
\hline & (1) & (2) & (3) & (4) \\
\hline & $\begin{array}{c}\text { Host- } \\
\text { Country } \\
\text { FE }\end{array}$ & $\begin{array}{l}\text { Host- and } \\
\text { Source- } \\
\text { Country FE }\end{array}$ & $\begin{array}{c}\text { Gravity } \\
\text { Variables }\end{array}$ & $\begin{array}{c}\text { Model } \\
\text { for } \\
\text { Prediction }\end{array}$ \\
\hline $\begin{array}{l}\text { Border } \\
\text { Language } \\
\text { Colony } \\
\text { Log(Distance) } \\
\text { Time Difference } \\
\log \left(G D P p c_{j t}\right) \\
\text { Exchange Rate } \\
\text { Volatility } \\
\text { Index Liberalization } \\
\quad \text { Equity } \\
j t\end{array}$ & & & $\begin{array}{c}0.820^{* * *} \\
(0.185) \\
1.729^{* * *} \\
(0.143) \\
-0.792^{* * *} \\
(0.203) \\
-0.453^{* * *} \\
(0.074) \\
-0.107^{* * *} \\
(0.017)\end{array}$ & $\begin{array}{c}0.820^{* * *} \\
(0.187) \\
1.736^{* * *} \\
(0.141) \\
-0.805^{* * *} \\
(0.192) \\
-0.433^{* * *} \\
(0.072) \\
-0.110^{* * *} \\
(0.017) \\
4.063^{* * *} \\
(0.769) \\
-0.003^{* *} \\
(0.001) \\
2.452^{* * *} \\
(0.603)\end{array}$ \\
\hline $\begin{array}{l}N \\
R^{2} \\
\text { Marginal } R^{2} \text { of } \\
\text { Gravity Variables } \\
\text { Marginal } R^{2} \text { of } \\
\text { Time-Varying } \\
\text { Variables } \\
\end{array}$ & $\begin{array}{l}1341 \\
0.46\end{array}$ & $\begin{array}{l}1341 \\
0.55\end{array}$ & $\begin{array}{l}1341 \\
0.71 \\
0.29\end{array}$ & $\begin{array}{l}1341 \\
0.72\end{array}$ \\
\hline $\begin{array}{l}\text { Notes: Robust standar } \\
\text { percent level, }{ }^{* *} \text { at the } \\
\text { (4) includes time dumm } \\
\text { percentage improvemen } \\
\text { the model with only hos } \\
\text { varying variables indica } \\
\text { varying variables (inclu } \\
\text { effects and the gravity }\end{array}$ & $\begin{array}{l}\text { rrors are } \\
\text { percent le } \\
\text { The ma } \\
\text { the } R^{2} \\
\text { nd source } \\
\text { the perc } \\
\text { g time d } \\
\text { ables. }\end{array}$ & $\begin{array}{l}\text { arentheses. }{ }^{*} \mathrm{~d} \\
\text { and }{ }^{* * *} \text { at the } \\
\text { al } R^{2} \text { of the gr } \\
\text { a including thes } \\
\text { intry fixed effec } \\
\text { ge improvemen } \\
\text { nies) over and }\end{array}$ & $\begin{array}{l}\text { notes signi } \\
1 \text { percent } \\
\text { avity variab } \\
\text { e variables, } \\
\text { s. The mar } \\
\text { t in the } R^{2} \\
\text { above the } n\end{array}$ & $\begin{array}{l}\text { ce at the } 10 \\
\text { indicates the } \\
\text { r and above } \\
R^{2} \text { of time- } \\
m \text { the time- } \\
\text { l with fixed }\end{array}$ \\
\hline
\end{tabular}


The set of time-varying controls includes GDP per capita in country $j$, bilateral exchange rate volatility, and the degree of openness of country $j$ to inward equity investment. ${ }^{7}$ The results suggest that investors invest more in countries that are more open to inward equity investment and have a larger GDP per capita. They also invest more when the volatility of the bilateral exchange rate is smaller. However, these time-varying variables do not have a large explanatory power and lead to a very small improvement in the $R^{2}$.

As for FDI, the index of openness to inward equity investment is used to estimate missing data. However, while for FDI it was possible to take a data point when the host country was still closed and build the data backwards using the growth rate of its total liabilities (as illustrated in table 3), for equity the data start when all countries were already open. Since it is not possible to build the data backwards in the same way as for FDI, we simply impose zero bilateral weights for the period when the host country was closed to inward equity investment. ${ }^{8}$

We also experimented with other control variables. To capture stock market returns and correlations in returns, we included averages, standard deviations, and the correlation coefficient of daily stock market indices in the host and source countries. These variables were insignificant and were not included in the final regression. GDP per capita in country $i$, stock market capitalization in country $j$, and trade weights were also insignificant.

\footnotetext{
${ }^{7}$ The degree of openness to inward equity investment was constructed in the same way as for FDI. In fact, FDI can be seen as a type of portfolio equity investment where the degree of ownership exceeds 10 percent of the firm's equity. Countries may liberalize their stock markets to foreign portfolio equity investment and remain closed to FDI by introducing a ceiling on the percentage of total equity that can be owned by foreign residents. The only country in our sample where the index of liberalization is different for equity and FDI is Korea, where foreign portfolio equity investment was partially liberalized in 1991, while foreign FDI investment remained restricted. Both types of investment were fully liberalized in 1998.

${ }^{8}$ The only exception to this rule is equity investment of Hong Kong in China. China was closed to inward equity investment until 1992. However, given the strong political and administrative links between the two countries, we do not impose zeros for Hong Kong's equity investment in China pre-1992.
} 


\subsection{Debt}

\subsubsection{Data}

Data on portfolio debt assets are collected from the IMF CPIS and the BIS locational banking statistics. The BIS data set has the advantage of having a much longer time coverage, going back to 1977 for most advanced countries. However, it has the limitation of only reporting debt assets held by banks, while the CPIS has much broader coverage. The data sets also differ in the assets covered: while the CPIS only covers portfolio debt, the BIS also covers loans and deposits.

To test whether it is sensible to combine data from the BIS and the CPIS, we compute the correlation coefficient between the asset weights generated by the two data sources. The correlation coefficient is large ( 80 percent), suggesting that it is reasonable to combine them. By default, we use asset weights computed from the BIS data and complete it with weights computed from the CPIS data whenever possible. After combining the two data sets, approximately 43 percent of the data are missing (table 2). The gaps are especially pronounced for China, which is not covered by either data set, and for countries not covered by the BIS locational banking statistics, for which we only have data after the CPIS was introduced in 1997.

As for the other asset classes, we make no use of data on liabilities. For CPIS data we face the same problems as with equity: very few countries report liabilities and, where they do, there is a large difference between liabilities and assets reported by creditors. For BIS data we cannot use liabilities to build assets by symmetry because the data are not symmetric: banks in country $i$ report assets held against banks and non-banks in country $j$, while banks in country $j$ report liabilities against both banks and non-banks in country $i$.

\subsubsection{Estimation}

Table 6 reports the results of estimating model (1) on debt weights. The model with only host-country fixed effects explains 49 percent of the variation in debt weights. Adding source-country fixed effects increases the $R^{2}$ to 57 percent, and adding standard gravity variables further improves the $R^{2}$ to 69 percent. Common border was excluded 
Table 6. Estimation Results for Debt Weights

\begin{tabular}{|c|c|c|c|c|}
\hline & (1) & (2) & (3) & (4) \\
\hline & $\begin{array}{c}\text { Host- } \\
\text { Country } \\
\text { FE }\end{array}$ & $\begin{array}{c}\text { Host- and } \\
\text { Source- } \\
\text { Country FE }\end{array}$ & $\begin{array}{c}\text { Gravity } \\
\text { Variables }\end{array}$ & $\begin{array}{c}\text { Model } \\
\text { for } \\
\text { Prediction }\end{array}$ \\
\hline Language & & & $1.081^{* * *}$ & $1.001^{* * *}$ \\
\hline & & & $(0.077)$ & $(0.081)$ \\
\hline Colony & & & $\begin{array}{c}-0.261^{* * *} \\
(0.078)\end{array}$ & $\begin{array}{c}-0.170^{* *} \\
(0.082)\end{array}$ \\
\hline $\log ($ Distance $)$ & & & & $-0.367^{* * *}$ \\
\hline Time Difference & & & $\begin{array}{c}-0.119^{* * *} \\
(0.010)\end{array}$ & $\begin{array}{c}-0.114^{* * *} \\
(0.010)\end{array}$ \\
\hline $\log \left(G D P p c_{j t}\right)$ & & & & $\begin{array}{l}0.892^{* * *} \\
(0.120)\end{array}$ \\
\hline Trade Weights $_{i j t}$ & & & & $\begin{array}{l}1.160^{* * *} \\
(0.449)\end{array}$ \\
\hline \multirow{2}{*}{$\begin{array}{c}\text { Exchange Rate } \\
\text { Volatility }_{i j t}\end{array}$} & & & & $-0.003^{* * *}$ \\
\hline & & & & $(0.001)$ \\
\hline \multirow{4}{*}{$\begin{array}{l}N \\
R^{2} \\
\text { Marginal } R^{2} \text { of } \\
\text { Gravity Variables } \\
\text { Marginal } R^{2} \text { of } \\
\text { Time-Varying } \\
\text { Variables }\end{array}$} & 4187 & 4187 & 4187 & 4187 \\
\hline & 0.49 & 0.57 & 0.69 & 0.70 \\
\hline & & & 0.21 & \\
\hline & & & & 0.01 \\
\hline \multicolumn{5}{|c|}{$\begin{array}{l}\text { Notes: Robust standard errors are in parentheses. }{ }^{*} \text { denotes significance at the } 10 \\
\text { percent level, }{ }^{* *} \text { at the } 5 \text { percent level, and }{ }^{* * *} \text { at the } 1 \text { percent level. Regression } \\
\text { (4) includes time dummies. The marginal } R^{2} \text { of the gravity variables indicates the } \\
\text { percentage improvement in the } R^{2} \text { from including these variables, over and above } \\
\text { the model with only host- and source-country fixed effects. The marginal } R^{2} \text { of time- } \\
\text { varying variables indicates the percentage improvement in the } R^{2} \text { from the time- } \\
\text { varying variables (including time dummies) over and above the model with fixed } \\
\text { effects and the gravity variables. }\end{array}$} \\
\hline
\end{tabular}

from the set of gravity variables because it had no significant effect on debt weights. The colony dummy has a negative sign, as in the model for equity. This suggests that for types of investment which imply a larger degree of commitment, such as FDI, former colonizers tend to invest in former colonies. However, for equity and debt 
investment they seem to prefer countries with a similar degree of development regardless of colonial links.

As for equity, the results suggest that investors tend to invest larger shares in more-developed countries - the Lucas paradox - and in countries with lower exchange rate volatility with respect to the currency of the source country. In contrast with the result for FDI and equity, bilateral trade weights have a significant and positive effect on debt weights. This is consistent with the findings in Rose and Spiegel (2004), who show that borrowers fear that default on their debt may lead to a reduction in international trade; therefore, creditors systematically lend more to countries with whom they have closer trade links. ${ }^{9}$

We experimented with additional controls and estimated the model including bond market capitalization and measures of bond returns. These variables turned out insignificant and were not included in the model used for prediction.

\subsection{Reserves}

The construction of the reserves data follows a different approach. While for FDI, equity, and debt investors choose where to invest, for reserves they choose in which currency to invest. We follow a twostep procedure to obtain the geographical composition of reserves. First, we obtain the currency composition. Then we translate it into the geographical composition: if country $i$ holds an amount $X$ of reserves in U.S. dollars, we take $X$ as being the amount of reserve assets that country $i$ holds in the United States. For simplification we focus on the four main reserve currencies: the U.S. dollar, the euro, the pound, and the yen. These capture the bulk of countries' foreign exchange reserves. Also for simplification we treat reserves of country $i$ denominated in euros as being assets of country $i$ in

\footnotetext{
${ }^{9}$ Unlike for FDI and equity, the set of time-varying controls does not include the degree of liberalization of the host country to inward debt investment. This is because we were unable to construct an index which captures restrictions only to inward investment. A time-series index for capital account restrictions is available in Kaminsky and Schmukler (2003). This captures restrictions to borrowing abroad by banks and corporations (which could be interpreted as restrictions to debt capital inflows) as well as exchange rates and other restrictions to capital outflows. Because it confounds restrictions to inward and outward investment, we decided not to use it.
} 
Germany. For the period before the introduction of the euro we use the deutsche mark. ${ }^{10}$

Data on the currency composition of reserves are confidential and not readily available. The BIS Multilateral Surveillance Statistics contain data on the currency composition of reserves for countries in the G-10 since 1994. This gives us data for six countries in our sample: France, Germany, Italy, Japan, the United Kingdom, and the United States. Given the remarkable stability of currency weights over time, we assume that weights stay constant from 1980 to 1994. For the remaining countries the IMF collects data in the COFER (Currency Composition of Official Foreign Exchange Reserves) data set. Although the numbers are only released as aggregates across industrialized and developing countries, disaggregated data have been used in some previous studies. We follow the approach in Lane and Shambaugh (2007) and use the results reported in those studies to obtain estimates of the currency composition of reserves for countries that are not part of the G-10.

The studies we use are Dooley, Lizondo, and Mathieson (1989) and Eichengreen and Mathieson (2000), who adopt the following specification to explain the currency composition of reserves:

$$
\begin{aligned}
\text { share }_{i c t}= & c+\alpha_{1} \text { dollar peg }_{i c t}+\alpha_{2} \text { other }_{\text {peg }} \text { ict } \\
& +\beta \text { share trade } \text { ijt }+\gamma \text { share debt payments } \\
i c t & +\varepsilon_{i c t} .
\end{aligned}
$$

The dependent variable is the share of foreign exchange reserves held by country $i$ in currency $c$ at time $t$, obtained from COFER. The regression includes dummy variables equal to 1 if country $i$ pegs to the U.S. dollar or to another currency, the share of trade between country $i$ and country $j$ at time $t$ (where country $j$ is the country that issues currency $c$ ), and the share of debt service payments of country $i$ in currency $c$ at time $t$. The share of trade is calculated as the sum of exports and imports between countries $i$ and $j$ divided by total exports plus imports plus debt service payments of country $i$. The share of debt payments in currency $c$ is calculated as

\footnotetext{
${ }^{10} \mathrm{~A}$ more precise way of dealing with euro reserves would be to allocate them according to the relative GDP of each country in the euro area. Here we take a shortcut and allocate all euro reserves to Germany.
} 
service payments of country $i$ on debt denominated in currency $c$ divided by total exports plus imports plus debt service payments of country $i$.

Eichengreen and Mathieson (2000) report the results of estimating this model for a sample of eighty-four emerging and transition economies for the period 1979-96. We collect data for the right-handside variables and multiply by the estimated coefficients reported in their paper to obtain estimates of the currency composition of reserves. ${ }^{11}$

Data on exchange rate regimes are obtained from Levy-Yeyati and Sturzenegger (2005). They report an index which classifies exchange rate regimes in three categories: floating, intermediate, and fixed. We transform this index into a binary variable, which takes the value 0 if the country has a floating regime and 1 if the country has an intermediate regime or a peg. We construct one indicator for U.S. dollar pegs and another for other currency pegs. Data on trade are collected from the IMF Direction of Trade Statistics. Debt service payments are obtained by multiplying the six-month euro currency deposit rates, obtained from Datastream, by the amount of debt outstanding, obtained from the World Bank's Global Development Finance.

This approach gives us estimates of the currency composition of reserves which seem sensible when compared with the reserve shares that countries occasionally report in announcements and media interviews. For example, China is reported to hold roughly 70 percent of its reserves in dollars, 20 percent in euros, and 10 percent in other currencies. Our estimation gives 79 percent in dollars and 21 percent in euros.

\section{A Look at the Data}

The international financial system can be seen as a network, where nodes represent countries and links represent bilateral financial assets. Our data set provides information on the links and allows us to study how the global financial network has changed over time.

\footnotetext{
${ }^{11}$ We use the coefficients reported in table 3 of Eichengreen and Mathieson (2000).
} 
In this section we use network methods to give a flavor of the data set and show the key stylized facts that emerge from it.

\subsection{Financial Network}

Figure 2 looks at the evolution of the global financial network. In each year $t$ links are given by the ratio of bilateral assets (including all asset classes) to GDP of the source country:

$$
\operatorname{link}_{i j t}=\frac{\text { Assets }_{i j t}}{G D P_{i t}} .
$$

The network is directed: an arrow pointing from county $i$ to $j$ represents the value of country $i$ 's assets in country $j$ scaled by country $i$ 's GDP. It is also weighted because links represent the strength of the connections between nodes and not simply whether a connection exists or not. To simplify the diagrams, we impose a cutoff and represent only the strongest links (where the ratio defined above is higher than 1.7 percent). This cutoff is chosen in such a way that every node is linked to at least one other node in every year. The thickness of the lines indicates the size of the links, and the size of the nodes is proportional to the country's financial openness, measured by the sum of its total external assets and liabilities. Pairs of countries with stronger links are placed closer to each other. ${ }^{12}$

Table 7 provides some summary statistics. Skewness is a measure of the asymmetry of a distribution. A positive value indicates that there are many country pairs with small links and few country pairs with large links. Kurtosis is a measure of the "peakedness" of a distribution. A large value for kurtosis indicates that the distribution has "fat tails." ${ }^{13}$ Average path length is the average of the shortest distance between all pairs of nodes in the network. Clustering measures the probability that, given that country $i$ is directly linked to countries $j$ and $k$, country $j$ is also directly linked to country $k$. Small

\footnotetext{
${ }^{12}$ This is achieved using the Kamada-Kawai algorithm, which positions nodes in the space so that their geometric distance reflects the strength of the links between them. The network charts were produced using Pajek (a program for analysis and visualization of large networks).

${ }^{13} \mathrm{~A}$ normal distribution has skewness equal to 0 and kurtosis equal to 3 .
} 


\section{Figure 2. International Financial Network}

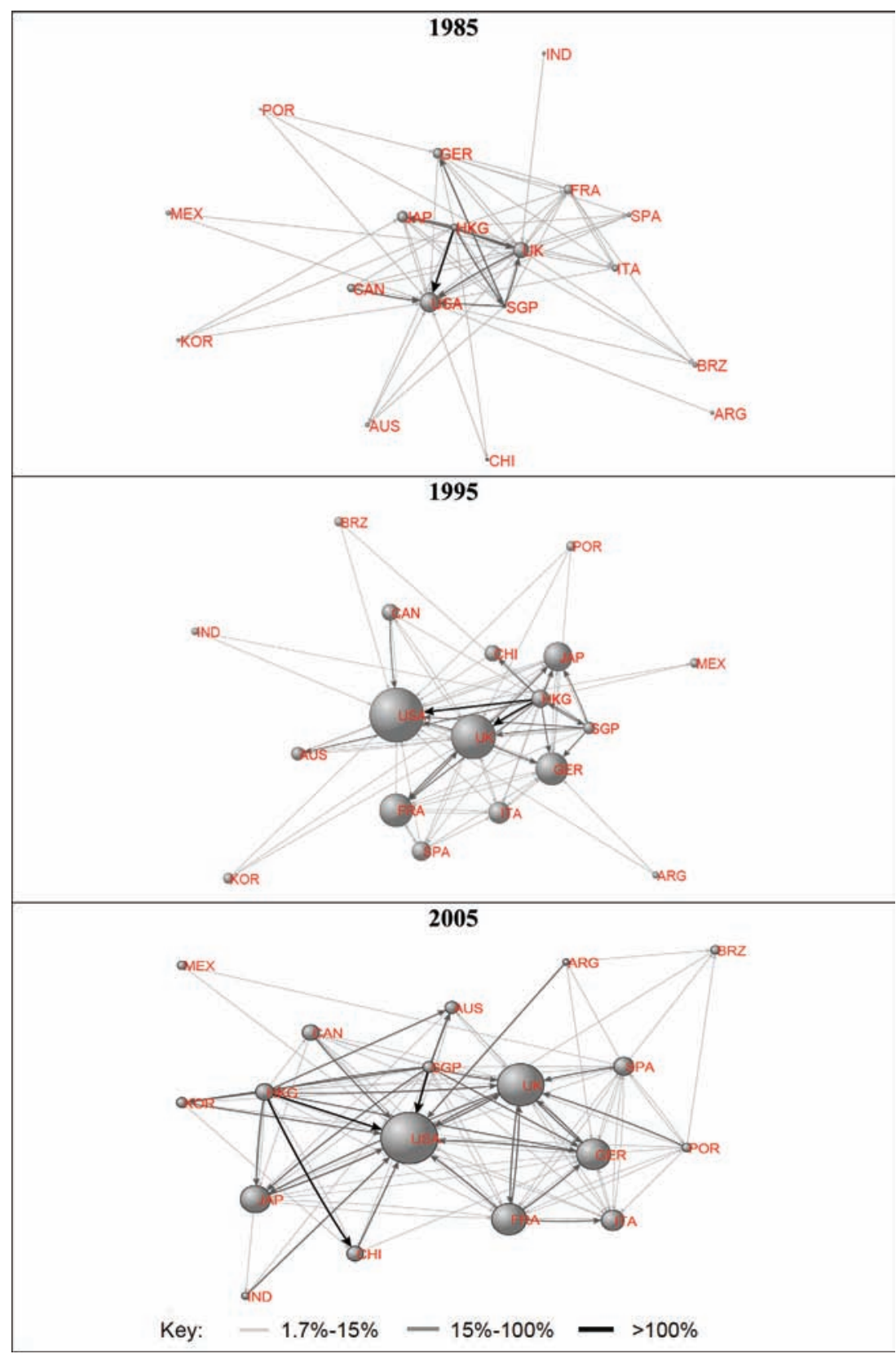

Notes: Links are given by the ratio of bilateral assets to GDP of the source country. The size of the nodes is proportional to the country's financial openness, measured by the sum of its total external assets and liabilities. 


\section{Table 7. Summary Statistics on the International Financial Network}

\begin{tabular}{|l|r|r|r|}
\hline & $\mathbf{1 9 8 5}$ & $\mathbf{1 9 9 5}$ & $\mathbf{2 0 0 5}$ \\
\hline Skewness & 7.63 & 7.16 & 5.22 \\
Kurtosis & 69.60 & 61.55 & 35.27 \\
Average Path Length & 2.07 & 2.14 & 1.93 \\
Clustering Coefficient & 0.55 & 0.63 & 0.60 \\
\hline
\end{tabular}

values for average path length and large values for the clustering coefficient indicate that the network is highly interconnected. ${ }^{14}$

A few findings emerge:

- The interconnectivity of the global financial network has increased significantly over the past two decades. This can be seen from the increase in the size of the nodes and the increase in number and size of the links. It is also confirmed by the large values of the clustering coefficient and the reduction in average path length over time. In 2005 there are less than two degrees of separation on average between any two nodes.

- The distribution of financial links exhibits a long tail. Measures of skewness and kurtosis show the asymmetry compared with the normal distribution. A small number of countries ("hubs") have large links to other countries, but most links are small.

To study which countries are the main sources and destinations of international investment, table 8 reports measures of network centrality for each node (country), following the approach of von Peter (2007).

The key findings that emerge from the centrality measures are as follows:

\footnotetext{
${ }^{14}$ Detailed definitions of these statistics are presented in the appendix. Average path length and clustering depend on the cutoff chosen for the links. Imposing a cutoff enables us to apply these statistics (which were developed for unweighted networks) to our network. Because the global financial network is complete-i.e., all pairs of nodes are linked even if the size of financial assets and liabilities is very small - these statistics would be meaningless if we had not imposed a cutoff.
} 


\begin{tabular}{|c|c|}
\hline 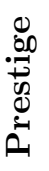 & 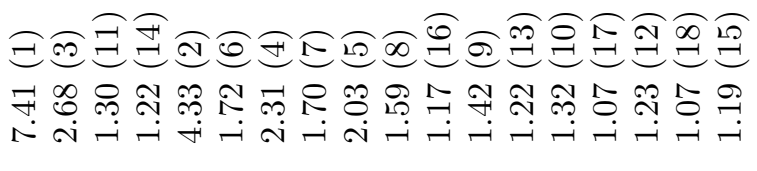 \\
\hline 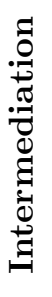 & 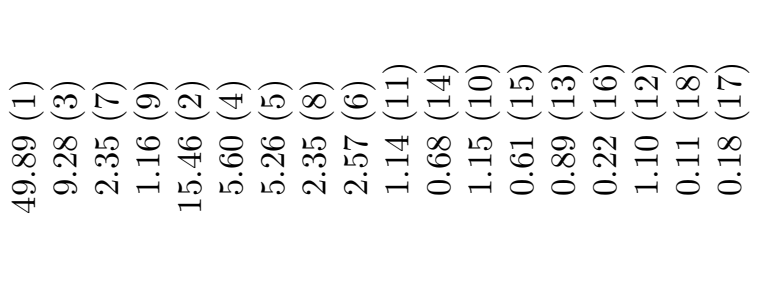 \\
\hline $\begin{array}{l}0 \\
0 \\
0 \\
\Xi \\
0 \\
0 \\
\vdots \\
0 \\
0 \\
0\end{array}$ & 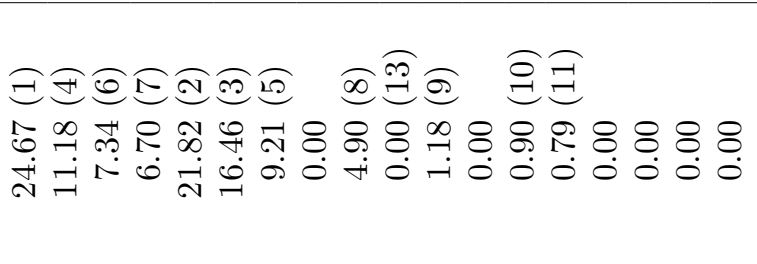 \\
\hline$\frac{\infty}{\bigcup_{0}^{\infty}}$ & 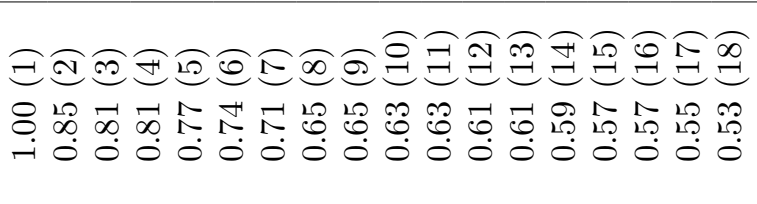 \\
\hline 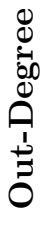 & 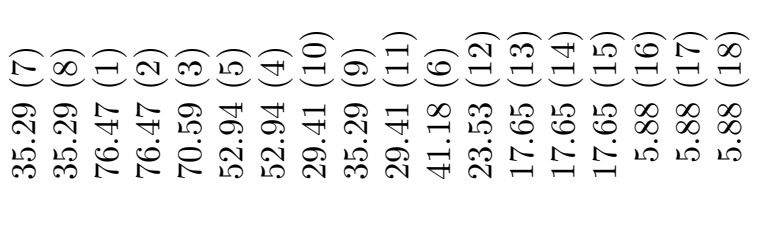 \\
\hline$\bigotimes_{\substack{\infty \\
\infty}}^{\infty}$ & 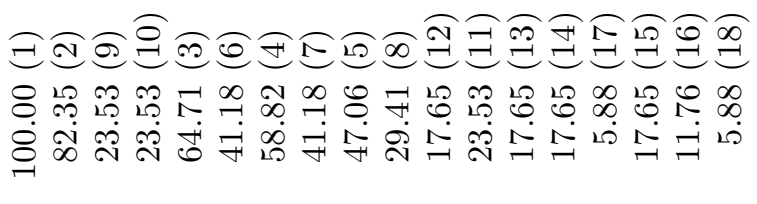 \\
\hline & 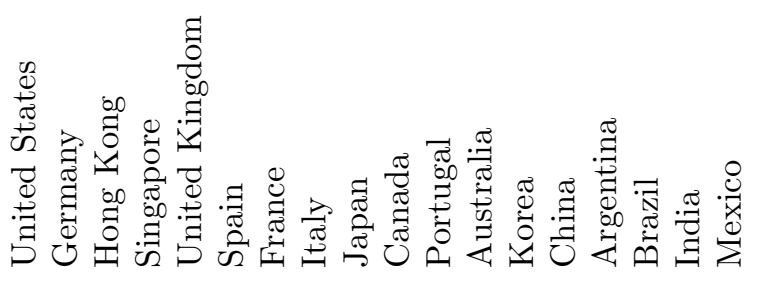 \\
\hline
\end{tabular}


- The United States, the United Kingdom, and Germany are the main recipients of foreign investment. This can be seen by the number of arrows pointing to these nodes and by the high value of in-degree centrality, which measures the number of links that arrive at a node divided by the maximum number of links.

- Financial centers-Hong Kong, Singapore, and the United Kingdom - are the main originators of foreign investment, as can be seen by the number of arrows pointing out and the high value of out-degree centrality, which measures the number of links that depart from a node divided by the maximum number of links.

- The countries which are located closer to other nodes in the network are the United States, Germany, Hong Kong, Singapore, and the United Kingdom. Closeness centrality is the inverse of the average distance between countries, where distance is measured by the number of links on the shortest path. A country which is directly connected to all other countries, such as the United States, has a closeness score equal to 1.

- The United States and the United Kingdom are the main countries connecting other nodes. This is captured by betweenness centrality, which measures the frequency with which a country lies on the shortest path between two other countries, and intermediation centrality, which captures the intensity of links by incorporating portfolio shares.

- The United States and the United Kingdom also score highest in terms of prestige centrality. Prestige centrality (or eigenvector centrality) reflects the importance of the counterparties. A country with high prestige is one that is linked to others that have high prestige themselves.

\subsection{Financial Network-Asset Composition}

To analyze differences across asset classes, figure 3 represents the networks with links given by the ratio of assets to GDP of the source country for each asset class in $2005 .{ }^{15}$ Centrality measures have also been calculated for each of these networks.

\footnotetext{
${ }^{15}$ The cutoff for deletion of the smallest links is 0.3 percent for FDI and equity and 1 percent for debt. No cutoff is imposed for reserves.
} 
Figure 3. International Financial Network by Asset Class, 2005

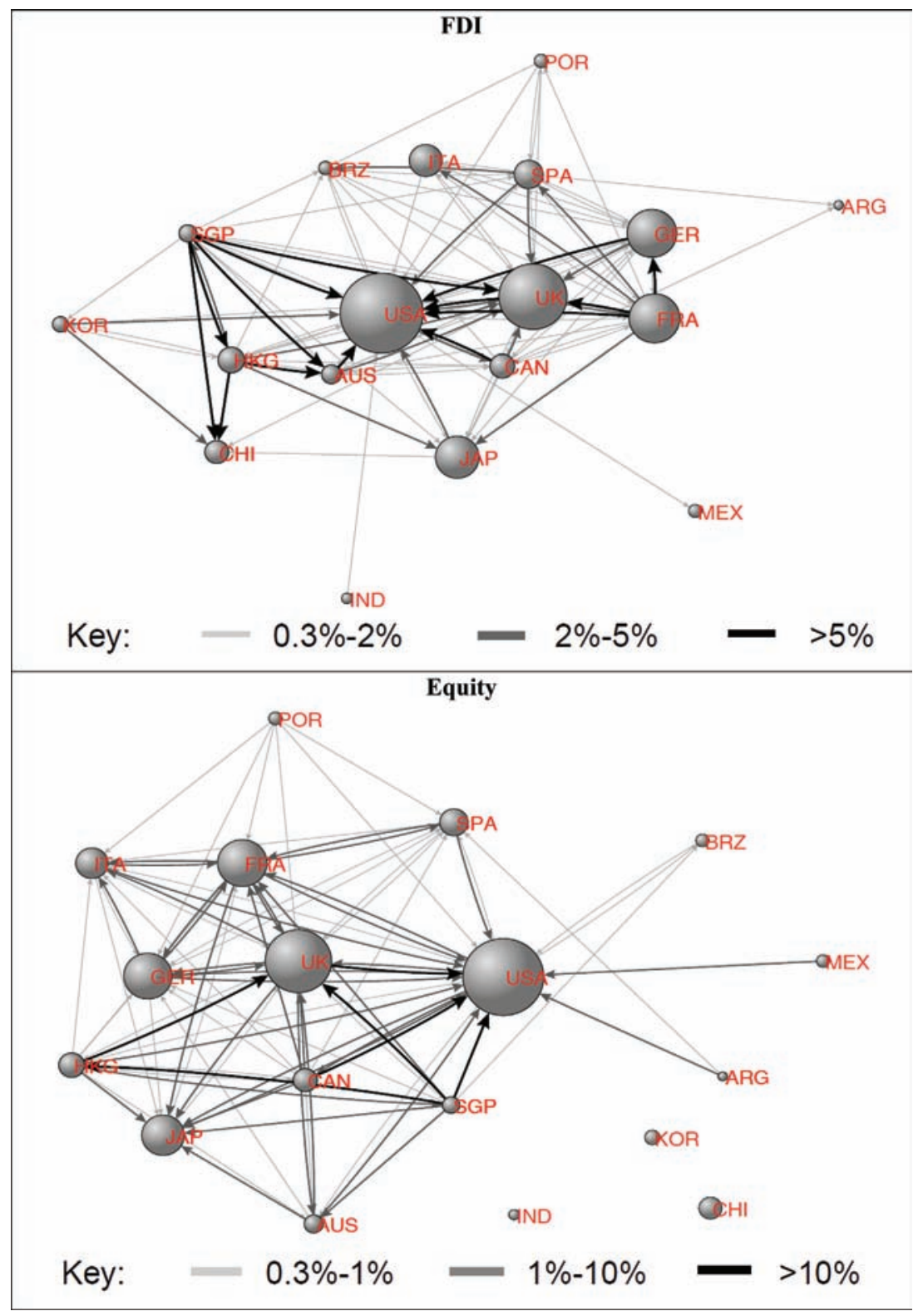

(continued) 


\section{Figure 3. (Continued)}

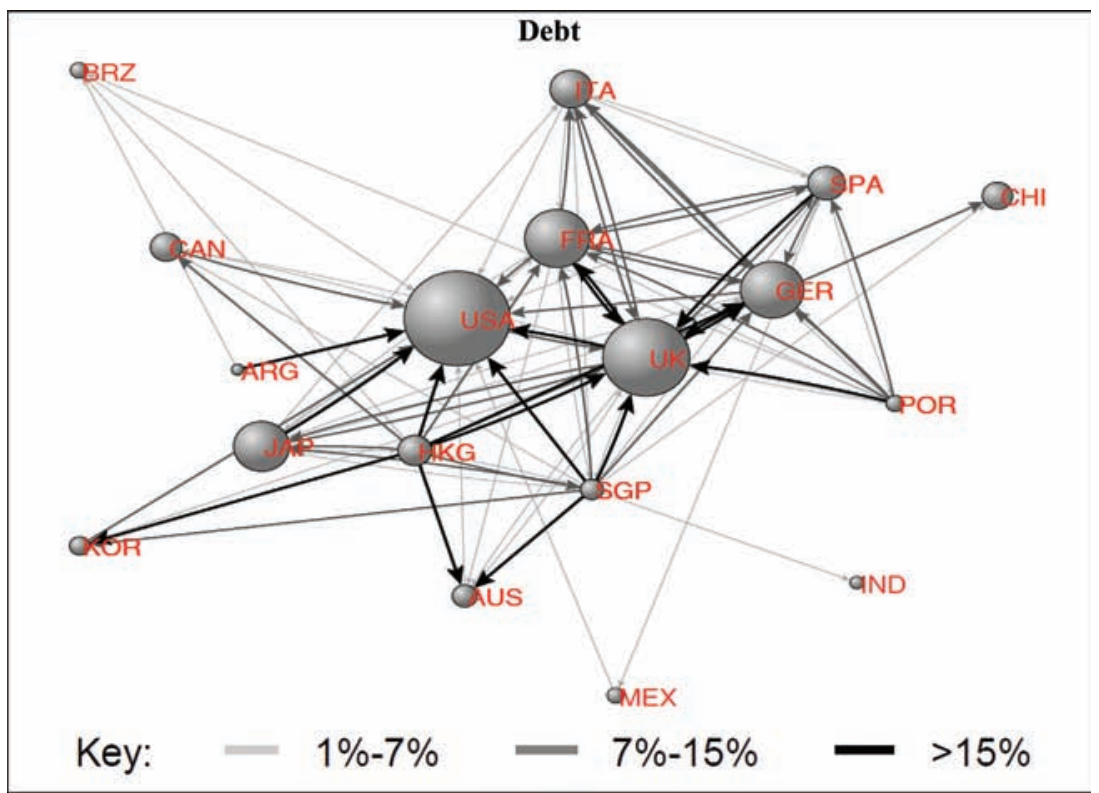

\section{Reserves}

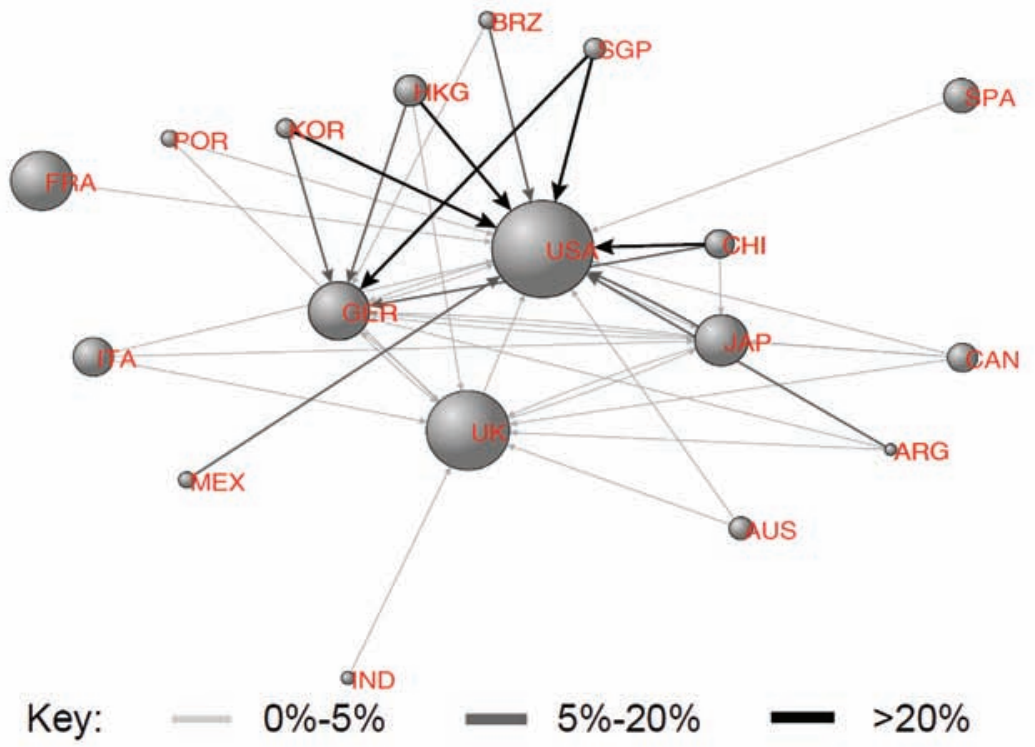

Notes: Links are given by the ratio of bilateral assets to GDP of the source country for each asset class. The size of the nodes is proportional to the country's financial openness, measured by the sum of its total external assets and liabilities. 
Table 9. Summary Statistics on the International Trade Network

\begin{tabular}{|l|r|r|r|}
\hline & $\mathbf{1 9 8 5}$ & $\mathbf{1 9 9 5}$ & $\mathbf{2 0 0 5}$ \\
\hline Skewness & 6.55 & 6.73 & 5.67 \\
Kurtosis & 53.03 & 55.93 & 42.90 \\
Average Path Length & 1.56 & 1.67 & 1.89 \\
Clustering Coefficient & 0.36 & 0.39 & 0.48 \\
\hline
\end{tabular}

The United States and the United Kingdom emerge as the main recipients of foreign investment for FDI, equity, and debt and have the highest scores for in-degree centrality. Singapore and Hong Kong score low as recipients of foreign investment, but they score high as originators. There are some interesting differences across asset classes. The equity network is less dense than for other asset classes, with some countries (China, Korea, and India) being unconnected. The United States is ranked first in out-degree centrality for FDI and second for equity investment, but is ranked only tenth as originator of debt investment. This is consistent with the finding that U.S. foreign assets tend to be composed mostly of equity and FDI, while its foreign liabilities tend to be composed mostly of bonds (Gourinchas and Rey 2007a). For reserves, the network is less dense because we only measure reserve holdings in four currencies: dollars, euros, pounds, and yens. Among these currencies, the dollar is clearly dominant. The large arrow linking China to the United States reflects the large value of China's foreign exchange reserves: over US $\$ 0.8$ trillion in 2005, most of which was held in dollar assets. This value has increased steadily to over US $\$ 2.3$ trillion in 2009 .

\subsection{Comparison with the Trade Network}

Table 9 reports summary statistics and figure 4 represents the directed trade network. Links are given by the ratio of bilateral exports to GDP of the source country:

$$
\operatorname{link}_{i j t}=\frac{\text { Exports }_{i j t}}{G D P_{i t}}
$$




\section{Figure 4. International Trade Network}

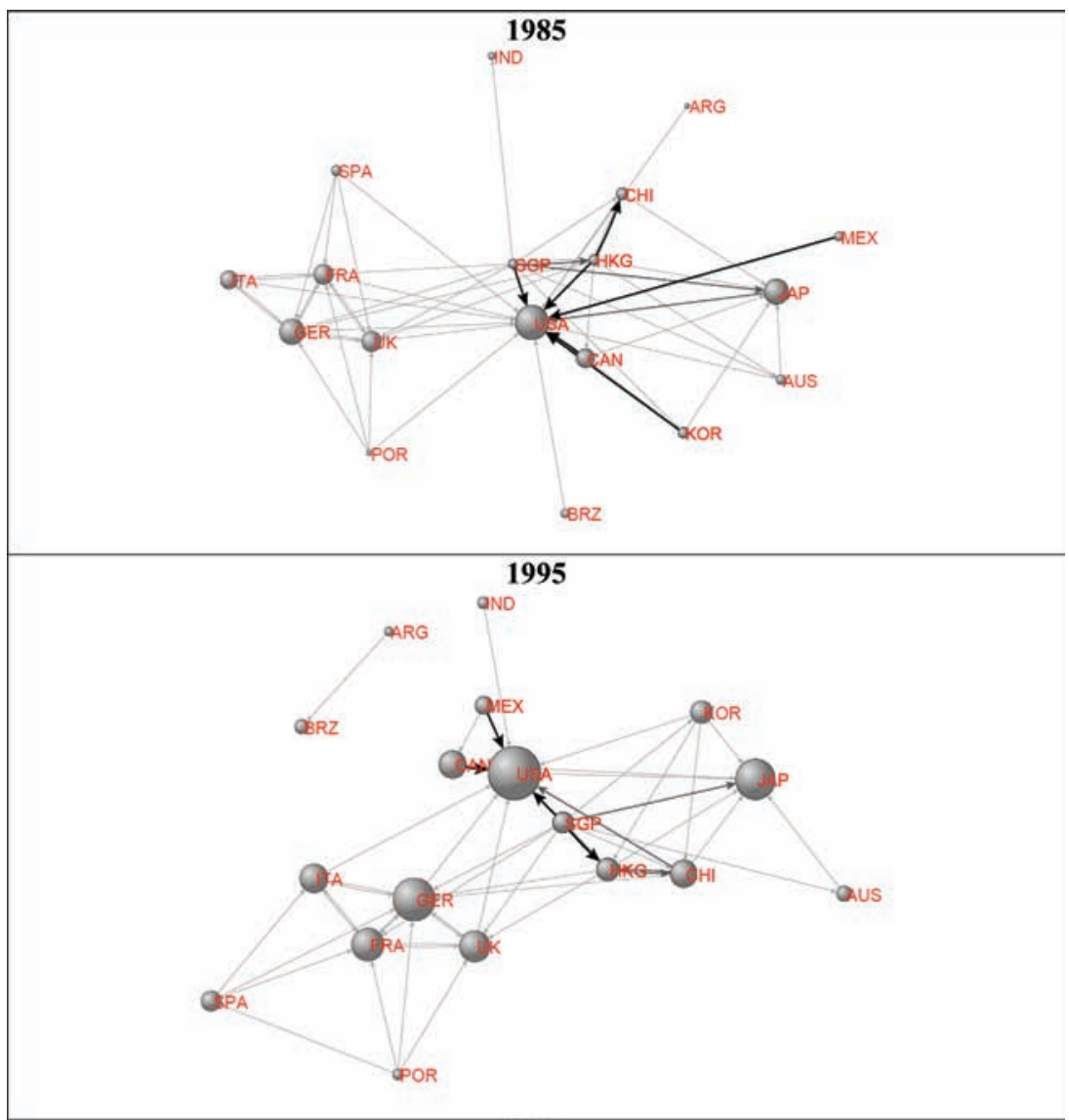

2005

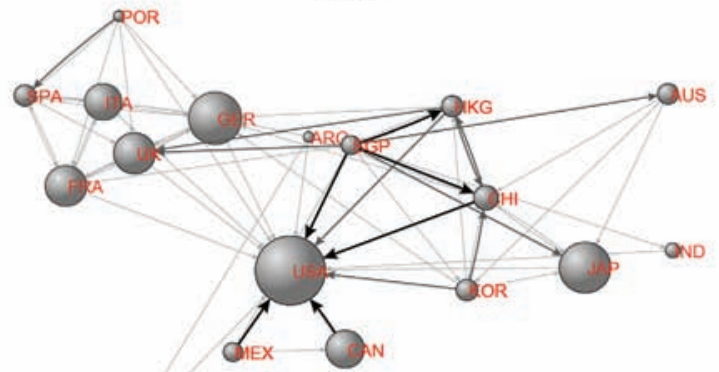

ORZ

Key: $-1.3 \%-5 \%-5 \%-10 \%->10 \%$

Notes: Links are given by the ratio of bilateral exports to GDP of the source country. The size of the nodes is proportional to the country's trade openness, measured by the sum of its total exports and imports. 
An arrow pointing from $i$ to $j$ is proportional to the value of country $i$ 's exports to country $j$, divided by the GDP of country $i{ }^{16}$ The thickness of the lines is proportional to the size of the links, and the size of the nodes is proportional to the country's trade openness, measured by the sum of total exports and imports. Data on bilateral trade are from the IMF Direction of Trade Statistics (DOTS).

A few findings emerge:

- Just as for the global financial network, the interconnectivity of the global trade network increased over the last two decades. This can be seen from the increase in the size of the nodes and the increase in the size and number of links.

- The distribution of trade links also exhibits a long tail with a small number of countries having large links. This asymmetry in the distribution can be seen from the large values of skewness and kurtosis.

To identify which countries play a central role in the trade network, measures of centrality in 2005 are given in table 10. These measures highlight some additional facts:

- In all years the trade network exhibits strong intracontinental links with three clusters: an American cluster (United States, Canada, and Mexico), an Asian cluster (Singapore, Hong Kong, China, Korea, and Japan), and a European cluster (United Kingdom, Germany, France, Spain, Italy, and Portugal). This pattern contrasts with the one found for financial links, where the United Kingdom and the United States were clearly at the center of the network linking to almost all other nodes.

- Germany, China, and France are important trade centers and score highly both as exporters and as importers. The United States is the main importer but scores low as an exporter. The opposite is true for Singapore, which is the main exporter but scores low as an importer.

\footnotetext{
${ }^{16}$ Links for which this ratio is below 1.3 percent are not shown in the figure. This cutoff is set so that every node is linked to at least one other node.
} 


\begin{tabular}{|c|c|c|}
\hline 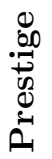 & 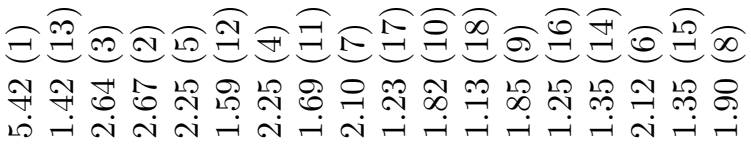 & 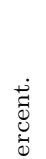 \\
\hline : & 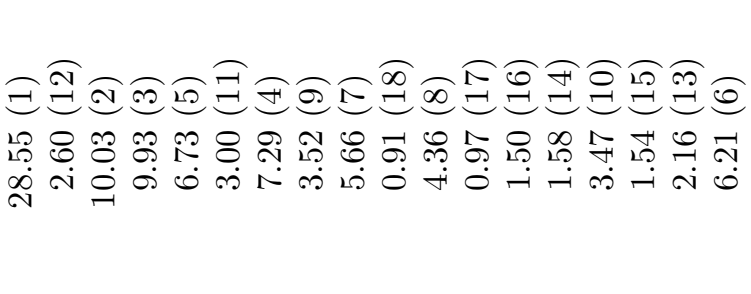 & 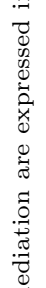 \\
\hline 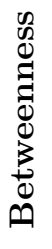 & 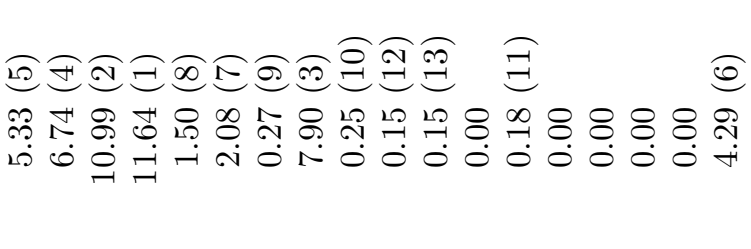 & 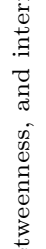 \\
\hline 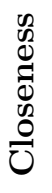 & 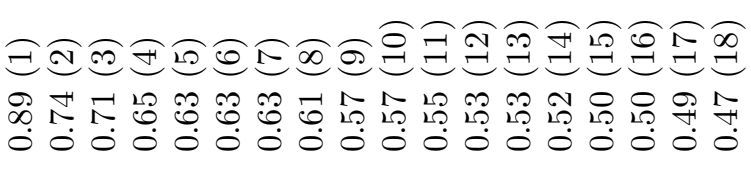 & $\begin{array}{l}0 \\
0 \\
0 \\
0.0 \\
0 \\
0 \\
1 \\
\vdots \\
0 \\
0 \\
0\end{array}$ \\
\hline$\underbrace{0}_{\substack{0 \\
\infty}}$ & 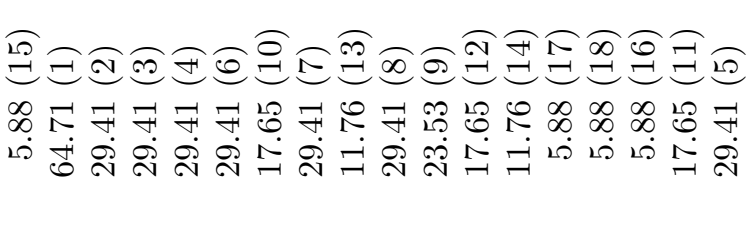 & 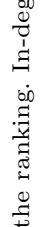 \\
\hline 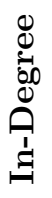 & 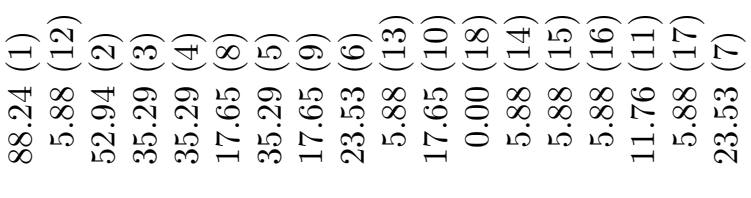 & 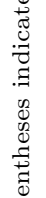 \\
\hline & 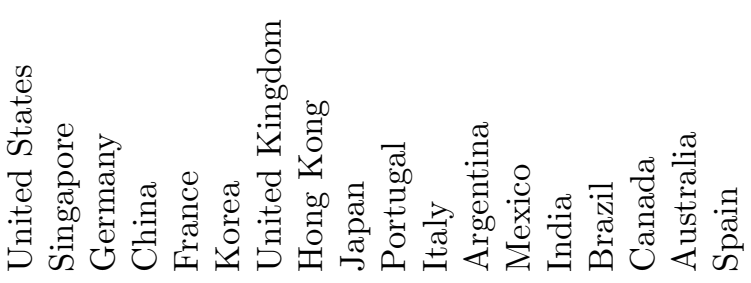 & 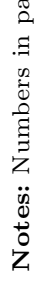 \\
\hline
\end{tabular}


- Germany appears to be the center of the European cluster and China appears to be the center of the Asian cluster. These countries play an important role connecting other nodes, as can be seen by their high scores for betweenness and intermediation centrality.

- The United Kingdom occupies a much less central position in the trade network than in the financial network.

\section{Implications for the Stability of the International Financial System}

Higher interconnectivity entails a fundamental trade-off. On the one hand, it enhances risk sharing by allowing countries to better diversify idiosyncratic risks. On the other hand, it increases the risk of contagion. If a shock hits a highly interconnected country, its creditors will suffer losses because the profitability of their investment falls. This could generate a cascade of losses through the system.

The international financial network has long tails, with some countries having multiple and large links. A long-tailed distribution of links is a property of "scale-free" networks, whose robustness has been studied, for example, by Albert, Jeong, and Barabási (2000). Their study shows that these networks are robust to random shocks: since the majority of the nodes have only a few small links, there is a higher probability that a random shock will hit a less-connected node. However, they are very vulnerable to targeted attacks hitting the most-connected nodes.

Low average path length and a high clustering coefficient are characteristics of the so-called "small-world" networks described, for example, in Watts and Strogatz (1998). In contrast to "scale-free" networks, these networks do not exhibit much variability in the number of links of each node. This suggests that they are not particularly vulnerable to targeted attacks. However, because they are characterized by a high degree of interconnectivity, once an attack occurs, it will tend to spread more widely.

The global financial network exhibits characteristics of both "scale-free" and "small-world" networks. Because the network has a small number of nodes with multiple and large links and is highly interconnected, it is susceptible to targeted attacks affecting the key 
financial hubs. Disturbances to those hubs would spread rapidly and generate large losses throughout the network. ${ }^{17}$

To study how shocks would spread through the network, we take the configuration of links in 2005 and simulate the losses to the network following a 10 percent reduction in the value of all countries' assets in country $i$ (the shock country). For example, if the shock originates in the United States, we start by reducing the value of other countries' assets in the United States by 10 percent. This gives the losses in the first round. In the second round, countries that hold assets in U.S. creditor countries will suffer as well because the profitability of those assets is reduced due to the losses that these countries suffer on their exposures to the United States.

To illustrate, suppose that Spain has assets in the United States and the United Kingdom and that the United Kingdom also has assets in the United States. In the first round, both Spain and the United Kingdom lose 10 percent of the value of their assets in the United States. In the second round, Spain loses on its assets in the United Kingdom due to the losses that the United Kingdom incurred because of its exposure to the United States. The first round of contagion reflects losses on direct exposures to the shock country. Later rounds of contagion reflect losses on indirect exposures. The appendix discusses the simulation in detail.

Table 11 reports losses for all countries in the network following a reduction of 10 percent in their asset values in the United States. Losses are reported both in value and in percentage of the GDP of the impact country. The countries that suffer the largest losses in percentage of GDP following a shock to the United States are the other "hubs" in the network: Hong Kong, Singapore, and the United Kingdom. ${ }^{18}$ Figure 5 plots total losses to the network in each round following a U.S. shock. Losses are measured as a fraction of the sum of the GDP of all countries except the United States. The impact of the shock is largest in the first round and decays exponentially in subsequent rounds. This suggests that the largest losses occur due to direct exposures.

\footnotetext{
${ }^{17}$ These properties of the global financial network and its consequences for stability are discussed in Haldane (2009).

${ }^{18}$ Argentina also suffers significant losses in the first round because of its large exposure to the United States in 2005, which is apparent in figure 2.
} 
Table 11. Losses Following a Shock to the United States

\begin{tabular}{|l|r|r|r|r|}
\hline \multirow{2}{*}{ Impact on } & \multicolumn{2}{|c|}{ Value (\$US millions) } & \multicolumn{2}{c|}{ \% of GDP } \\
\cline { 2 - 5 } & Round 1 & \multicolumn{1}{c|}{ Total } & Round 1 & Total \\
\hline Hong Kong & 25624.96 & 83484.78 & 14.41 & 46.95 \\
Singapore & 15405.77 & 38968.57 & 13.20 & 33.39 \\
United Kingdom & 192073.50 & 343368.15 & 8.61 & 15.38 \\
Argentina & 13179.33 & 14515.94 & 7.19 & 7.92 \\
Canada & 51272.34 & 72980.79 & 4.53 & 6.45 \\
Japan & 193610.96 & 288804.83 & 4.26 & 6.35 \\
Korea & 24747.97 & 31970.43 & 3.13 & 4.04 \\
France & 65220.41 & 218109.49 & 3.05 & 10.21 \\
Australia & 21593.70 & 33628.65 & 2.93 & 4.56 \\
China & 65181.36 & 82130.22 & 2.90 & 3.66 \\
Germany & 65987.52 & 189934.63 & 2.37 & 6.82 \\
India & 12408.78 & 14513.42 & 1.54 & 1.80 \\
Mexico & 11416.76 & 11981.94 & 1.49 & 1.56 \\
Spain & 9219.23 & 64210.37 & 0.82 & 5.70 \\
Portugal & 1507.00 & 10168.07 & 0.81 & 5.49 \\
Brazil & 6431.20 & 8611.10 & 0.73 & 0.98 \\
Italy & 10775.55 & 60657.80 & 0.61 & 3.43 \\
\hline Total Impact & $\mathbf{7 8 5 6 5 6 . 3 3}$ & $\mathbf{1 5 6 8 0 3 9 . 1 6}$ & $\mathbf{3 . 4 7}$ & $\mathbf{6 . 9 3}$ \\
\hline Notes: The table reports losses following a shock that reduces the value of all coun- \\
tries' assets in the United States by 10 percent. Losses in round 1 come from direct \\
exposures to the United States. Losses in later rounds are due to indirect exposures, \\
via other countries. The total represents the sum of all losses up to round 8. The last \\
two columns report losses in percentage of the GDP of the impact country. \\
\hline \multicolumn{4}{|c|}{} \\
\hline
\end{tabular}

The transmission of the shock would be very different it had originated in a peripheral country. Table 12 reports losses following a 10 percent reduction in asset values in Brazil. The countries most affected in the first round are the ones with the strongest links to Brazil - in particular, Spain, Portugal, and Argentina. As further rounds of losses take place, the shock spreads to other countries, especially to the most interlinked ones. When looking at total losses after eight rounds, the countries that suffer the most are the financial centers of Hong Kong, Singapore, and the United Kingdom. Still, these losses are very small compared with the ones that would occur following a shock to the United States. 


\section{Figure 5. Total Losses in Each Round Following a Shock to the United States}

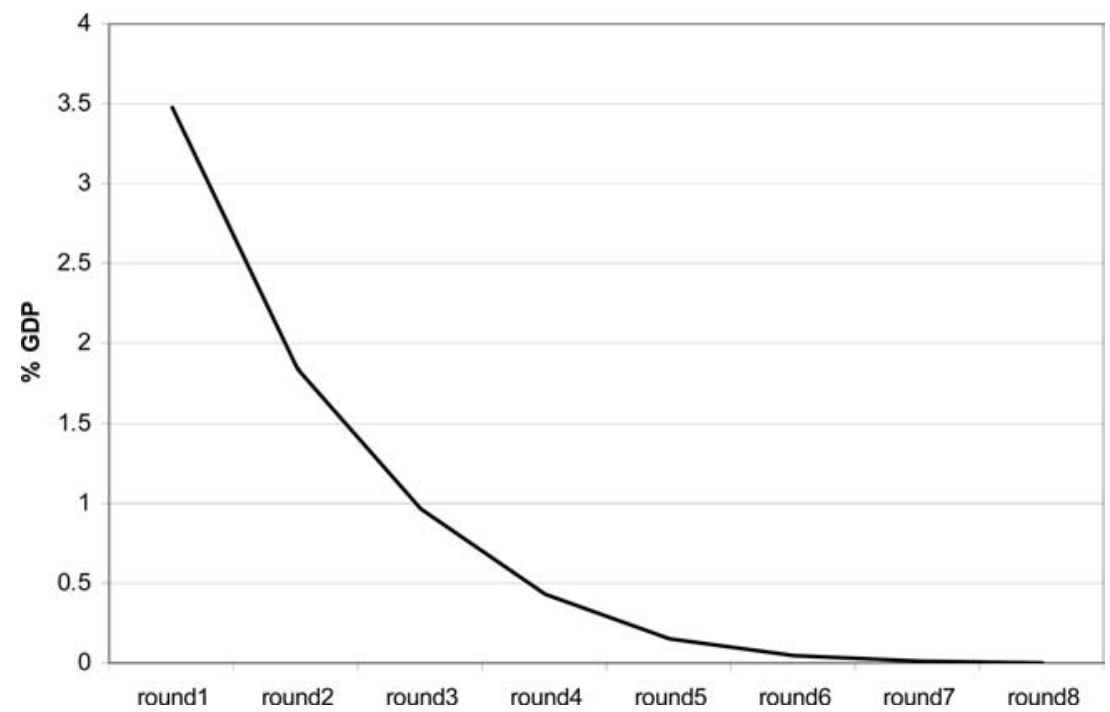

To understand which countries can generate the largest losses to the system, table 13 reports total losses following shocks to each country in the network. A shock to the United States is by far the most harmful, generating losses equal to 7 percent of the combined GDP of all countries except the United States. Shocks to the United Kingdom, Germany, France, and Japan also generate considerable losses. The shocks that generate the smallest losses are the ones to peripheral countries: shocks to Argentina, India, Portugal, Mexico, and Brazil generate losses of less than 0.4 percent of the combined GDP of all countries except the shock country.

This simulation looks at countries' total external assets regardless of their composition. It implicitly assumes that losses are propagated in the same way for FDI, equity, debt, and reserve assets. It should be noted, however, that different types of assets have different risk-sharing abilities. In particular, contingent asset classes (such as FDI and portfolio equity) offer better opportunities for risk sharing than non-contingent assets classes (such as bonds or bank loans). In addition, FDI is more long term in nature and would be less vulnerable to shocks than shorter-term instruments. 
Table 12. Losses Following a Shock to Brazil

\begin{tabular}{|l|r|r|c|c|}
\hline \multirow{2}{*}{ Impact on } & \multicolumn{2}{|c|}{ Value (\$US millions) } & \multicolumn{2}{c|}{ \% of GDP } \\
\cline { 2 - 5 } & Round 1 & Total & Round 1 & Total \\
\hline Spain & 3584.90 & 6742.75 & 0.32 & 0.60 \\
Portugal & 543.52 & 1162.40 & 0.29 & 0.63 \\
Argentina & 483.53 & 1073.31 & 0.26 & 0.59 \\
Hong Kong & 278.54 & 4172.56 & 0.16 & 2.35 \\
United States & 14503.47 & 24279.07 & 0.12 & 0.20 \\
France & 2259.17 & 14104.14 & 0.11 & 0.66 \\
Canada & 1088.34 & 4148.63 & 0.10 & 0.37 \\
United Kingdom & 2067.86 & 18298.52 & 0.09 & 0.82 \\
Singapore & 103.97 & 1975.13 & 0.09 & 1.69 \\
Germany & 1768.44 & 12014.89 & 0.06 & 0.43 \\
Italy & 1096.79 & 4611.42 & 0.06 & 0.26 \\
Japan & 1258.00 & 14152.77 & 0.03 & 0.31 \\
Australia & 140.89 & 1652.49 & 0.02 & 0.22 \\
Korea & 69.82 & 1470.70 & 0.01 & 0.19 \\
Mexico & 10.78 & 513.45 & 0.00 & 0.07 \\
India & 9.42 & 633.08 & 0.00 & 0.08 \\
China & 22.86 & 3683.81 & 0.00 & 0.16 \\
\hline Total Impact & $\mathbf{2 9 2 9 0 . 3 1}$ & $\mathbf{1 1 4 6 8 9 . 1 3}$ & $\mathbf{0 . 0 9}$ & $\mathbf{0 . 3 4}$ \\
\hline Notes: The table reports losses following a shock that reduces the value of all coun- \\
tries' assets in Brazil by 10 percent. Losses in round 1 come from direct exposures \\
to Brazil. Losses in later rounds are due to indirect exposures, via other countries. \\
The total represents the sum of all losses up to round 8. The last two columns report \\
losses in percentage of the GDP of the impact country. & & \\
\hline
\end{tabular}

Hence, we would expect countries whose external assets are dominated by short-term debt instruments to suffer more losses following a shock than countries whose external assets are composed mostly of FDI. This is confirmed in the study of Milesi-Ferretti and Tille (2010), which finds that the retrenchment in international capital flows that occurred during the current financial crisis was more pronounced in countries with large net external liabilities in the form of debt. While we do not explore this issue, our data set can be used to study the role of different asset classes in the transmission of shocks. 


\section{Table 13. Total Losses Following Shocks to Each Country in the Network}

\begin{tabular}{|l|c|c|}
\hline Shock to & Value (\$US millions) & \% GDP \\
\hline United States & 1568039.16 & 6.93 \\
United Kingdom & 1268860.43 & 3.87 \\
Germany & 710879.23 & 2.21 \\
France & 633305.64 & 1.93 \\
Japan & 526333.97 & 1.73 \\
Italy & 411378.91 & 1.24 \\
Spain & 386418.14 & 1.14 \\
Canada & 335041.01 & 0.99 \\
Australia & 222762.98 & 0.65 \\
Hong Kong & 147660.26 & 0.42 \\
China & 136022.47 & 0.41 \\
Singapore & 136726.26 & 0.39 \\
Korea & 120970.69 & 0.35 \\
Brazil & 114689.13 & 0.34 \\
Mexico & 110800.01 & 0.32 \\
Portugal & 103376.24 & 0.30 \\
India & 42934.96 & 0.13 \\
Argentina & 36274.34 & 0.10 \\
\hline Notes: The table reports losses following a shock that reduces the value of all coun- \\
tries' assets in the shock country by 10 percent. Losses are an aggregate for all rounds \\
up to round 8. When reported as a percentage of GDP, losses are measured as a share \\
of the sum of the GDP of all countries in the network except the shock country. \\
\hline \multicolumn{2}{|l}{} \\
\hline
\end{tabular}

\section{Conclusions}

This paper contributes to the study of financial globalization by constructing a data set on bilateral financial links for a group of eighteen countries from 1980 to 2005 . We collect data from several sources and fill gaps using gravity models. Network tools are used to identify the key stylized facts that emerge from the data and to study the propagation of shocks to different countries in the network. We find a remarkable increase in interconnectivity over the past two decades, with an increase in the number and size of financial links. In addition, the distribution of financial links has a long tail, with a small number of countries having large and numerous links. 
The network exhibits some "small-world" properties, with a small number of degrees of separation between nodes and a high clustering coefficient. The combination of high interconnectivity, long-tails, and "small-world" properties makes for a robust yet fragile system, where disturbances to one of the central hubs would be transmitted widely and rapidly.

The trade network also reveals an increase in interconnectivity over time. However, unlike the financial network, where the United States and the United Kingdom are at the center and intracontinental links are not particularly strong, the trade network exhibits much stronger links within continents. In particular, there is a European cluster, centered around Germany; an Asian cluster, centered around China; and an American cluster, centered around the United States. The United Kingdom plays a much less central role in the trade network than in the financial network.

\section{Appendix}

\section{Statistical Definitions}

Skewness is a measure of the asymmetry of a distribution and is defined as $\frac{E(X-\mu)^{3}}{\left(E(X-\mu)^{2}\right)^{3 / 2}}$. A normal distribution is symmetric and has skewness equal to 0 . A positive value for skewness indicates that the distribution has a long tail on the right; i.e., there are many observations with small values of $X$ and few observations with large values of $X$.

Kurtosis is a measure of the "peakedness" of a distribution and is defined as $\frac{E(X-\mu)^{4}}{\left(E(X-\mu)^{2}\right)^{2}}$. A normal distribution has a kurtosis equal to 3. A large value for kurtosis indicates that the distribution has "fat tails."

\section{Network Definitions}

The network can be expressed in matrix form, where the typical element $A_{i j}$ records the value of financial assets held by country $i$ in country $j$. The matrix has dimension equal to the number of countries, $n$, and can be read in two directions: rows of $A$ represent assets of country $i$ in country $j$, and columns of $A$ represent liabilities of $j$ in $i$. All diagonal elements are zero. Off-diagonal elements are zero 
for country pairs whose links are below the cutoff, defined in such a way that each country is linked to at least one other country (either as a creditor or as a debtor). The network is directed and weighted, hence $A$ is not symmetric and its entries reflect the size of financial assets.

Two perspectives can be taken when analyzing weighted networks. One perspective looks at whether a link exists or not, regardless of the value of the link; i.e., it looks at the indicator $N_{i j}=1$ if $A_{i j}>0$, and 0 otherwise. Another perspective takes into account the size of the links $A_{i j}$.

Average path length is the average of the shortest paths between all pairs of nodes in the network. For example, if node $i$ is directly linked to node $k$, the shortest path between the two nodes has length 1. Average path length is the average of this measure for all pairs of nodes.

Clustering measures the probability that, given that node $i$ is directly linked to nodes $j$ and $k$, node $j$ is also directly linked to $k$. The clustering coefficient is given by $\frac{\sum_{i, j \neq i, k \neq j, k \neq i} N_{i j} N_{i k} N_{j k}}{\sum_{i, j \neq i, k \neq j, k \neq i} N_{i j} N_{i k}}$.

\section{Measures of Network Centrality}

The definitions of the centrality measures used in the paper follow closely the box in von Peter (2007). The centrality measures apply to each node and describe how that node relates to the network, taking different perspectives. Degree, closeness, and betweenness centrality are based on whether a link exists or not, regardless of the value of the link; i.e., they are based on the indicator $N_{i j}$. Intermediation and prestige centrality take into account the size of the links and rely on the portfolio shares $P_{i j}=A_{i j} / \sum_{k} A_{i k}$ for all $i$.

In-degree is the number of links that point to a node and is given by the sum $\sum_{j} N_{j i}$. Out-degree is the number of links departing from a node and is given by the sum $\sum_{j} N_{i j}$. The measures of in-degree and out-degree centrality reported in the tables scale these sums by the total possible number of links, $n-1$.

Closeness is the inverse of the average distance from node $i$ to all other nodes. The distance between $i$ and $j, \delta_{i j}$, equals the length of the shortest path. The average distance from $i$ to all other nodes is given by $\sum_{j} \delta_{i j} /(n-1)$. Closeness is the inverse of this measure. 
Betweenness focuses on the nodes that the shortest path goes through. Let $g_{j k}$ denote the number of shortest paths between $j$ and $k$, and let $g_{j k}(i)$ denote the number of such paths that go through node $i$. The probability that node $i$ is on the shortest path from $j$ to $k$ is given by $g_{j k}(i) / g_{j k}$. Betweenness of node $i$ is the sum of these probabilities over all nodes excluding $i$, divided by the maximum that the sum can attain: $\left(\sum_{j \neq i} \sum_{k \neq i} g_{j k}(i) / g_{j k}\right) /(n-1)(n-2)$.

Intermediation extends the betweenness measure, taking into account the value of the links. The probability that a dollar sent by $i$ reaches $j$ in two steps is given by $\sum_{k} P_{i k} P_{k j}$. The probability that a dollar sent by $i$ reaches $j$ through $k$ is given by $P_{i k} P_{k j} / \sum_{k} P_{i k} P_{k j}$. The intermediation measure for node $k$ is obtained by summing these probabilities for all pairs $(i, j)$, divided by the total number of pairs $n(n-1)$.

Prestige (or eigenvector centrality) considers the identity of the counterparties. The prestige of country $i\left(v_{i}\right)$ is obtained by taking the prestige of its creditors, weighted by their portfolio shares with $i$, i.e., $v_{i}=\sum_{j} P_{j i} v_{j}$. This defines a linear system $v=P^{\prime} v$, where $P$ is the matrix of portfolio shares. The solution to this system is the eigenvector associated with the unit eigenvalue. Following von Peter (2007), we solve the alternative system $v=\frac{1}{2} P^{\prime} v+e \Rightarrow$ $v=\left(I-\frac{1}{2} P^{\prime}\right)^{-1} e$, where $e$ is the unit vector. This avoids countries with a zero score contributing nothing to the centrality of others.

\section{Simulation Exercise}

To illustrate how losses to the network are calculated following a reduction of 10 percent in asset values in a given country, consider the hypothetical network with four countries shown in figure 6 . An arrow from country 2 to country 1 indicates that country 2 holds assets in country 1. Suppose there is a shock that reduces asset values in country 1 by 10 percent. In the first round, countries 2 and 4 suffer losses because they have a direct exposure to country 1 . Total losses in the first round equal $L^{\text {round } 1}=0.1 \times P_{21} \times A_{2}+0.1 \times P_{41} \times A_{4}$, where $P_{21}$ and $P_{41}$ are the portfolio shares of countries 2 and 4 in country 1 , and $A_{2}$ and $A_{4}$ are the values of these countries' total assets before the shock. In the second round, country 3 also suffers losses because it holds assets in countries 2 and 4 . The profitability 


\section{Figure 6. Hypothetical Network}

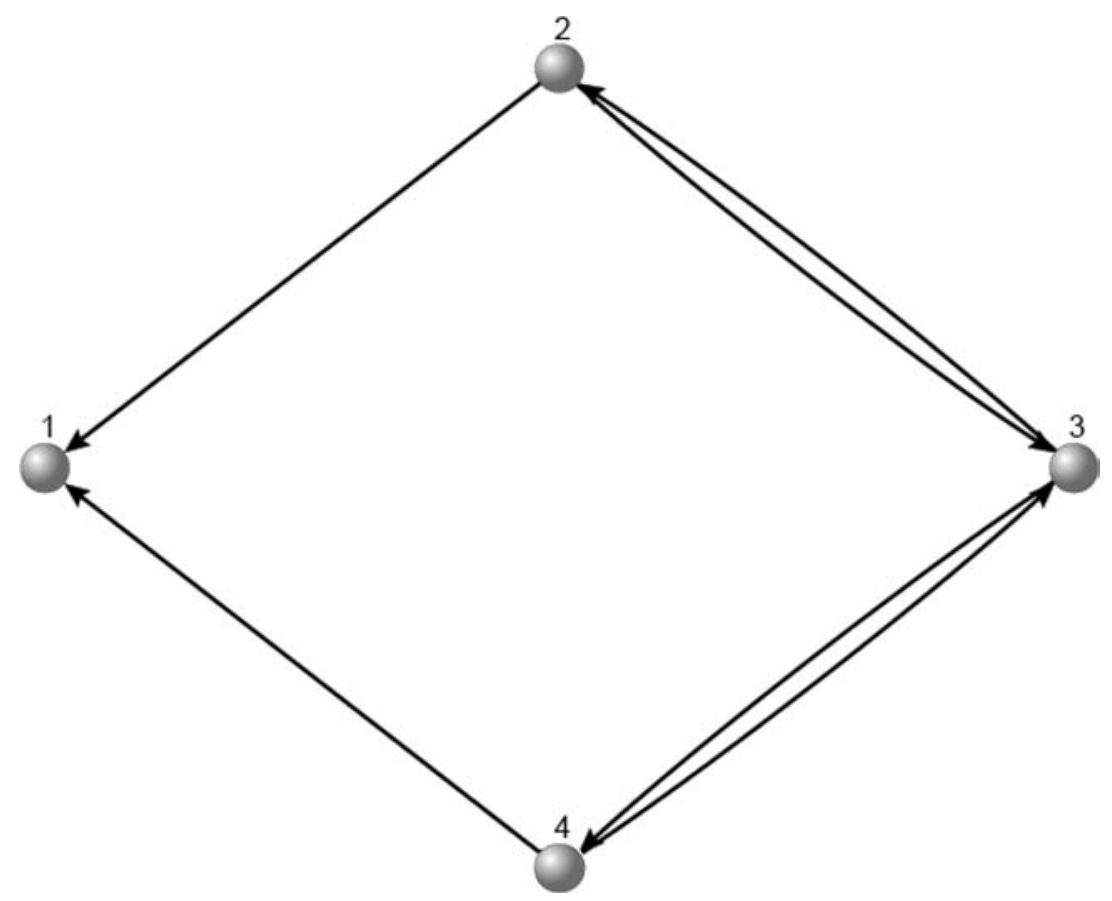

of these assets is reduced due to the losses that countries 2 and 4 suffer on their exposure to country 1 . Losses in the second round equal $L^{\text {round } 2}=0.1 \times\left(P_{32} \times P_{21}+P_{34} \times P_{41}\right) \times A_{3}$. The product of portfolio shares $P_{32} \times P_{21}$ can be interpreted as the exposure of country 3 to shock country 1 via country 2 . There is a third and final round of contagion, in which countries 2 and 4 lose on their assets in country 3 following the losses that country 3 suffered in the second round. Losses in the third round equal $L^{\text {round } 3}=0.1 \times P_{23} \times P_{34} \times P_{41} \times A_{2}+0.1 \times P_{43} \times P_{32} \times P_{21} \times A_{4}$.

Note that we rule out feedback loops. For example, in the third round, we only consider the losses that country 2 suffers because of the second-round losses of country 3 on its exposures to country 4. We do not consider the second-round losses that country 3 has on its exposures to country 2; i.e., we do not consider $0.1 \times P_{23} \times P_{32} \times P_{21} \times A_{2}$. This is a simplifying assumption to ensure that the simulation converges to an equilibrium where no 
further losses to the network occur. If we had allowed for feedback loops, there would always be further rounds of contagion and the simulation would not converge.

In the actual network considered in this paper, there are eighteen countries which are all linked to each other. Ruling out feedback loops, there would be seventeen rounds of contagion. For computational tractability, we only consider losses up to round 8. Given that losses decrease exponentially - as shown in figure 5-this is a good approximation to total losses.

\section{References}

Ahluwalia, M. 2002. "Economic Reforms in India Since 1991: Has Gradualism Worked?" Journal of Economic Perspectives 16 (3): $67-88$.

Albert, R., H. Jeong, and A. Barabási. 2000. "Error and Attack Tolerance of Complex Networks." Nature 406 (6794): 378-82.

Bekaert, G., C. Harvey, and C. Lundblad. 2007. "Financial Openness and the Chinese Growth Experience." Available at http://ssrn.com/abstract $=991640$.

Dooley, M., S. Lizondo, and D. Mathieson. 1989. "The Currency Composition of Foreign Exchange Reserves." IMF Staff Papers 36 (2): $385-434$.

Eichengreen, B., and D. Mathieson. 2000. "The Currency Composition of Foreign Exchange Reserves: Retrospect and Prospect." IMF Working Paper No. 00/131.

Felettigh, A., and P. Monti. 2008. "How to Interpret the CPIS Data on the Distribution of Foreign Portfolio Assets in the Presence of Sizeable Cross-Border Positions in Mutual Funds. Evidence from Italy and the Main Euro-Area Countries." Banca d'Italia Questioni di Economia e Finanza Occasional Paper No. 16 (August).

Gourinchas, P. O., and H. Rey. 2007a. "From World Banker to World Venture Capitalist: U.S. External Adjustment and the Exorbitant Privilege." In G7 Current Account Imbalances: Sustainability and Adjustment, ed. R. Clarida. Chicago: University of Chicago Press.

. 2007b. "International Financial Adjustment." Journal of Political Economy 115 (4): 665-703. 
Haldane, A. 2009. "Rethinking the Financial Network." Speech delivered at the Financial Student Association, Amsterdam. Available at http://www.bankofengland.co.uk/publications/ speeches/2009/speech386.pdf.

Kaminsky, G., and S. Schmukler. 2003. "Short-Run Pain, Long-Run Gain: The Effects of Financial liberalization." NBER Working Paper No. 9787.

Lane, P., and G. M. Milesi-Ferretti. 2001. "The External Wealth of Nations: Measures of Foreign Assets and Liabilities for Industrial and Developing Countries." Journal of International Economics 55 (2): 263-94.

- 2007. "The External Wealth of Nations Mark II: Revised and Extended Estimates of Foreign Assets and Liabilities, 19702004." Journal of International Economics 73 (2): 223-50.

. 2008. "International Investment Patterns." Review of Economics and Statistics 90 (3): 538-49.

Lane, P., and J. Shambaugh. 2007. "Financial Exchange Rates and International Currency Exposures." NBER Working Paper No. 13433.

Levy-Yeyati, E., and F. Sturzenegger. 2005. "Classifying Exchange Rate Regimes: Deeds vs. Words." European Economic Review 49 (6): 1603-35.

Lucas, R. 1990. "Why Doesn't Capital Flow from Rich to Poor Countries?" American Economic Review: Papers and Proceedings 80 (2): 92-96.

Martin, P., and H. Rey. 2004. "Financial Super-Markets: Size Matters for Asset Trade." Journal of International Economics 64 (2): $335-61$.

McGuire, P., and N. Tarashev. 2008. "Global Monitoring with the BIS International Banking Statistics." BIS Working Paper No. 244.

McGuire, P., and P. Wooldridge. 2005. "The BIS Consolidated Banking Statistics: Structure, Uses and Recent Enhancements." BIS Quarterly Review (September): 73-86.

Milesi-Ferretti, G. M., and C. Tille. 2010. "The Great Retrenchment: International Capital Flows During the Global Financial Crisis." Available at http://www.cepr.org/meets/wkcn/9/979/ papers/Milesi-Ferretti_Tille.pdf. 
OECD (Organisation for Economic Cooperation and Development). 2000. "Main Determinants and Impacts of Foreign Direct Investment on China's Economy." OECD Directorate for Financial, Fiscal and Enterprise Affairs, Working Paper on International Investment No. 2000/4.

Okawa, Y., and E. van Wincoop. 2010. "Gravity in International Finance." Hong Kong Institute for Monetary Research Working Paper No. 07/2010 (April).

Papaioannou, E. 2009. "What Drives International Financial Flows? Politics, Institutions and Other Determinants." Journal of Development Economics 88 (2): 269-81.

Portes, R., and H. Rey. 2005. "The Determinants of Cross-Border Equity Flows." Journal of International Economics 65 (2): 26996.

Prasad, E., and S. Wei. 2005. "The Chinese Approach to Capital Inflows: Patterns and Possible Explanations." IMF Working Paper No. 05/79.

Reserve Bank of India. 2006. "Report of the Committee on Fuller Capital Account Convertibility." Chapter 3. Available at http://www.rbi.org.in/scripts/PublicationReportDetails. aspx? fromdate $=09 / 1 / 06 \&$ SecId $=21 \&$ SubSecId $=$.

Rose, A., and M. Spiegel. 2004. "A Gravity Model of Sovereign Lending: Trade, Default, and Credit." IMF Staff Papers 51 (s1): $64-74$.

Stein, E., and C. Daude. 2007. "Longitude Matters: Time Zones and the Location of Foreign Direct Investment." Journal of International Economics 71 (1): 96-112.

von Peter, G. 2007. "International Banking Centres: A Network Perspective." BIS Quarterly Review (December): 33-45.

Watts, D., and S. Strogatz. 1998. "Collective Dynamics of 'SmallWorld' Networks." Nature 393 (6684): 409-410. 